\title{
The Republic of Palau and the United States: Self-Determmation Becomes the Price of Free Association
}

\author{
Jon Hinck $\uparrow$
}

United States conduct toward the island territories of the Pacific has been replete with broken promises and self-dealing. On the island of Palau, the evolution toward sovereignty has stalled because the United States refuses to concede defeat on the provisions of the Palau Constitution that outlaw nuclear power, nuclear weaponry, and a foreign power's exercise of eminent domain in Palau. The United States has refused to continue negotiations on the Compact of Free Association, arguing that validating those provisions jeopardizes U.S. security interests in Palau to an intolerable degree. In this Comment, the author argues that U.S. intransigence in regard to the Compact violates multiple provisions of international law. The author argues that the United States has violated both the Trusteeship Agreement and the Palauans' right of self-determination under customary international law. Furthermore, even if the Compact is now approved according to Palau's constitutional processes, the author argues that the agreement would be invalid under the international law of treaties.

\section{INTRODUCTION}

On February 6, 1990, the citizens of Palau, an island chain in the western Pacific, voted for the seventh time in a decade on whether to approve an agreement with the United States known as the Compact of Free Association. ${ }^{1}$ Under the Palauan Constitution, three-quarters of the electorate must approve the agreeinent in order for it to becoine effective. $^{2}$ The Coinpact requires $75 \%$ voter approval because it contains U.S.-imposed restrictions that would supersede certain provisions of the

$\dagger$ B.A. 1976, University of Pennsylvania; J.D. 1990, Boalt Hall School of Law, University of California, Berkeley. I would like to thank my advisor Professor Stefan Riesenfeld; Professor David Caron and Professor Roger Clark for additional advice; Julie Browne and Naomi Roht-Arriaza for comnients on drafts; and Mary Beth Braun and Sebia Hawkins for research assistance.

1. Compact of Free Association, Jan. 10, 1986, United States-Palau, 100 Stat. 3672 (codified as aniended at 48 U.S.C. $\S 1681$ (1988)) [hereinafter Conpact of Free Ass'n].

2. See Repub. of Palau Const. art. II, $\$ 3$, reprinted in Constitutions of DEPENDENCIES AND SPECIAL SOVEREIGNTIES 5 (A. Blaustein \& P. Blaustein eds. 1988). 
Palauan Constitution adopted overwhelmingly in $19800^{3}$ Those provisions effectively bar nuclear weapons, power, and waste, ${ }^{4}$ and prohibit the government from exercising its power of eminent domain for the benefit of foreign entities. ${ }^{5}$ The Compact vote in the February 1990 plebiscite, as in six prior votes, exceeded a simple majority but fell short of the required $75 \% .^{6}$

Adopting the Constitution, which became known as the world's first nuclear-free constitution, ${ }^{7}$ was to be one of the last steps taken before Palau gamed its sovereignty for the first time in 400 years. ${ }^{8}$ To coinplete the process, Palau must enter into an agreement with the United States, which is the admimistering authority under a 1947 trusteeship agreenent with the Umited Nations. ${ }^{9}$ The Umited States, however, has refused to negotiate any change in its relationship with Palau that would restrict the transit of U.S. nuclear-powered vessels or threaten the status of U.S. military bases. The Umited States has refused to negotiate on these points, claiming that they jeopardize its security interests. From the inception of the U.N. trusteeship, the United States has expressed its strategic interest in the islands. ${ }^{10}$ In fact, the Trusteeship Agreement between the United States and the U.N. Security Council recognized and affirmed a strategic U.S. role in the "maintenance of international peace and security" in the Pacific. $^{11}$

The same agreement obligated the United States to promote Palau's economic self-sufficiency and political development "toward self-government or independence" in accordance with the "freely expressed wishes of the people concerned."12 In addition, the United States pledged to uphold the U.N. Charter, which unequivocally states that the interests of the inhabitants of non-self-governing territories are "paramount," and which provides that promoting their well-being is "a sacred trust."13

3. See infra text accompanying notes 58-82.

4. See RePub. OF PAlAu CoNST. art. II, § 3, art. XIII, §6; see also infra note 125 (Palau trial court justice concluding that Palau Constitution effectively inakes Palau nuclear-free).

5. Repub. of Palau Const. art. XIII, $\$ 7$.

6. L.A. Times, Feb. 11, 1990, at A10, col. 3.

7. See, e.g., Palau Approves Nuclear Free Zone Constitution, Associated Press, July 17, 1980 (LEXIS, Nexis hibrary, AP file).

8. For a summary of Micronesia's colonial history, see Hirayasu, The Process of SelfDetermination and Micronesia's Future Political Status Under International Law, 9 U. HAw. L. REv. 487, 488-91 (1987).

9. See Trusteeship Agreement for the Former Japanese Mandated Islands, Apr. 2-July 18, 1947, United States-U.N. Security Council, art. 2, 61 Stat. 3301, T.I.A.S. No. 1665 [hereinafter Trusteeship Agreement].

10. See, e.g., 2 U.N. SCOR (113th mtg.) at 410 (1947) (statement of Warren R. Austin, U.S. Rep. to the United Nations).

11. Trusteeship Agreement, supra note 9, art. 5.

12. Id. art. 6.

13. See U.N. Charter art. 73, para. 1. Commentators have struggled for years to reach a workable formula to describe the administering authority's mission under the oxymoronic "strategic 
A divergence of interests between Palauans and U.S. military planners was therefore foreseeable, if not inevitable. The Palauans wanted their promised sovereignty; the United States wanted to protect its strategic interests. Not surprisingly, the first rift appeared during the drafting of Palau's Constitution in the late 1970s. ${ }^{14}$ Although the subsequently negotiated Coinpact has evolved over the ensuing decade, the conflict between the Palau Constitution and the Compact with the United States remains intractable so long as the Compact fails to gain $75 \%$ approval from Palau's voters.

Consequently, Palau's political situation remains essentially as it was in 1947 when the United Nations created the Trust Territory of the Pacific. The United States retains authority to engage in foreign relations on Palau's behalf, and even to run the Republic's doinestic affairs. Although Palau today is largely internally self-governing, four decades after the United States pledged to promote Palau's pohitical development, Palauans are still denied their sovereignty and the trusteeship continues. ${ }^{15}$

This Comment explores Palau's agonizing and so far futile efforts to terminate the trusteeship and enter into a nuutually acceptable agreeinent with the United States to end the prolonged era of trusteeship. The Comment argues that the United States has violated both the Trusteeship Agreement and the Palauans' right of self-determination under customary international law. Moreover, the Comment asserts that even if the Compact in its present form is now approved according to Palau's constitutional processes, the agreement would be void or voidable under the international law of treaties.

trust." In 1949, a writer described it as a "somewhat bastard and contradictory" concept. See A. McDonald, Trusteeship in the Pacific 54 (1949). Professor Prince, in one of the most recent articles on the trust territory, struggled to harmonize the strategic trusteeship's dual purposes: "[D]espite the undemiable primacy accorded to its security concerus, the Umited States ultimately made a binding commitment to make advancement of the Micronesian peoples the basic or paramount objective of the Trust Territory." Prince, The United States, the United Nations, and Micronesia: Questions of Procedure, Substance and Faith, 11 MICH. J. INT'L L. 11, 23 (1989).

14. See Staff of House COMM. ON Foreign Affairs, 96TH CONG, 1st Sess., Micronesian Political Status Negotiations: Report of a Staff Study Mission to Micronesia, November 4 To DeCember 1, 1978, at 7, 12 (Comm. Print 1979) (early drafts of the Constitution of the Federated States of Micronesia, successfully opposed by the United States, included a ban on testing and storage of nuclear material).

15. The failure to agree on the future pohtical status of Palau is apparently frustrating for both the United States and Palau. Compare, e.g., 134 CoNG. REc. H9763 (daily ed. Oct. 6, 1988) (statement of Hon. Ron de Lugo, Delegate to Congress from the Virgin Islands) [hereinafter Statement of De Lugo] (U.S. interests in the Compact include "ending the embarrassment of the U.S. being the last trust admimistrator") with Position Statement on the Future Political Status of Palau, signed by Hon. Ngiratkel Etpison, President of the Republic of Palau, and by presiding officers of Palau's legislative body, the Olbiil Era Kelulau (OEK) (Jan. 13, 1989) ("present status as the last Trust Territory smacks of a quasi-colonial status which is degrading to Palauan people and unworthy of America"). 
Part I summarizes the history of the U.S. administration of the Trust Territory of the Pacific, giving particular attention to the negotiations between the United States and Palau, the plebiscites that resulted in the adoption of the Palauan Constitution, and the repeated rejections of the Conipact of Free Association. Part II examines U.S. obhgations under the Trusteeship Agreement with the U.N. Security Council and concludes that the United States has violated that agreement. Part III then discusses the nature of additional U.S. obhgations under customary niternational law and concludes that the United States violated the Palauans' right of self-determination by undermining freely chosen constitutional provisions to protect Palau's environment and restrict foreign military activities in Palau. ${ }^{16}$ Finally, Part IV examines the validity of the Compact under the international law of treaties and concludes that it could be void or voidable even if now adopted pursuant to constitutional processes.

\section{BACKGROUND}

\section{A. U.S. Strategic Interests in Palau}

Palau is a group of 8 principal and 252 sinaller islands located 600 miles east of the Philippines and 4,450 miles southwest of Hawaii. ${ }^{17}$

16. This Comment does not attempt to analyze the international legal significance of nuclear weapons im the Palau controversy. The status of nuclear weapons under mternational law is itself a subject of significant debate. If nuclear weaponry is itself illegal, or its possession and use restricted under international law, an additional challenge could be made to the U.S. stance in Palau, where self-determination has been essentially conditioned on Palau's participation in the deployment of these weapons.

Significantly, the majority of commentators agree that international law himits the use of nuclear weapons. See Rosas, International Law and the Use of Nuclear Weapons, in Essays iN HONOUR OF ERIK CASTREN 73, 77-78 (1979) (summarizing the main views on the legality of nuclear weapons under international law); see also Brownlie, Some Legal Aspects of the Use of Nuclear Weapons, 14 INT'I \& COMP. L.Q. 437, 441-44 (1965) (nuclear weapons are prohibited by Geneva Gas Protocol because they qualify under provisions banning genocide and the use of poisonous and asphyxiating gas, and because targeting and casualties are inherently indiscriminate); Castren, The Illegality of Nuclear Weapons, 1971 U. ToL. L. REV. 89, 98 (prohibition against nuclear weapons is absolute, except perhaps where enemy uses nuclear weapons); Fried, International Law Prohibits the First Use of Nuclear Weapons, 16 Revue Belge de Droit InTERnational 33, 34 (1981) (while no treaty specifically forbids it, a first nuclear strike is prohibited by the "letter and spirit" of existing treaties); Meyrowitz, Les Juristes Devant l'Arme Nucléaire, 67 REvuE GÉNÉRALE DE DROIT INTERNATIONAL PUBLIC 820, 846-47 (1963) (use of nuclear weapons illegal because of the inevitability of "unnecessary suffering").

A few international lawyers go further and conclude that nuclcar weapons are inherently illegal. See, e.g., Corwin, The Legality of Nuclear Arms Under International Law, 5 DiCK. J. INT'L L. 271 (1987) (concluding that any use of nuclear weapons violates international law); Falk, Meyrowitz \& Sanderson, Nuclear Weapons and International Law, 20 INDIAN J. INT'L L. 541, 578 (1980) (concludimg that "global 'survivability' is so elemental to the international law of war that a prohibition on the use of nuclear weapons can be reasonably inferred").

17. The Far East And Australasia 1990, at 787 (Europa Pub. Ltd. 21st ed. 1990). 
Palau and the Federated States of Micronesia form the archipelago of the Caroline Islands, ${ }^{18}$ part of the Pacific region known as Micronesia, an expanse of ocean the size of the continental United States and dotted with 2,100 islands. ${ }^{19}$

Control over Micronesia essentially allows the United States to control the western Pacific. ${ }^{20}$ Since World War II, the greatest concern has been the threat of Soviet expansion in the region. ${ }^{21}$ Therefore, the prinuary strategic interest in controlling Micronesia is to deny hostile powers access to the region, ${ }^{22}$ and Palau's location makes it an important part of U.S. military strategy.

Palau's strategic value also stems from its location in the far western Pacific near major shipping routes. ${ }^{23}$ Moreover, Palau offers the best potential site for new U.S. bases if any such facilities are ever desired. ${ }^{24}$ In this regard, Palau is often mentioned as a likely "fall-back position" if the United States is ever displaced froin its two large military bases im the Philippines. ${ }^{25}$

\section{B. Establishment of Trusteeship}

Much of Micronesia, including Palau, was a major battle field dur-

18. $I d$.

19. Report of the United Nations Visiting Mission to the Trust Territory of the Pacific Islands, 1982, 50 U.N. TCOR Supp. (No. 2) at 2, U.N. Doc. T/1850 (1983).

20. D. Nevin, The AMerican TOUCh IN Micronesia 70 (1977).

21. See, e.g., Developments Regarding the Compact of Free Association Between the United States and Palau: Hearings on H.R.J. Res. 479 Before the Subcomms. on Human Rights and International Organizations, and on Asian and Pacific Affairs of the House Comm. on Foreign Affairs, 100th Cong., 2d Sess. 60 (1988) [hereinafter Hearings on H.R.J. Res. 479, Compact of Free Association] (statement of Karl D. Jackson, Deputy Ass't Sec'y of Defense) (United States "should expect a long and multi-faceted competition with the Soviet Union throughout the Pacific"). The extent to which warming U.S.Soviet relations may affect the Pacific region is unknown. Nonetheless, as the Iraq-Kuwait situation demonstrates, the end of the perceived Soviet threat does not mean the end of perceived threats from other quarters.

22. H. NUFER, MICRONESIA UNDER AMERICAN RULE 100 (1978).

23. See Hearings on H.R.J. Res. 479, Compact of Free Association, supra note 21, at 61 (statement of Karl D. Jackson).

24. See id.

25. See, e.g., id. at $64 ; \mathrm{H}$. NUFER, supra note 22 , at 100-01. The possibility of a U.S. pullout from the Philippines has been increasing over time. In June, the U.S. Peace Corps announced it would withdraw its 261 volunteers from the Philippines because of perceived threats to their safety. United Press International, Jnne 30, 1990 (LEXIS, Nexis library, UPI file). Philippine officials suggested that this U.S. move might negatively affect forthcoming negotiations on the future of U.S. military bases there. See id.; see also B. Aldridge \& C. Myers, Resisting the Serpent: PALAU's STRUGGLE FOR SElF-Determination 23-33 (1990) (examining Palau's military potential in some depth, and coneluding that Palau is the most logical location for a forward base for Trident submarines); Compact of Free Association: Hearing Before the Subcomm. on Public Lands and National Parks of the House Comm. on Interior and Insular Affairs, 98th Cong., 2d Sess. 178-81 (1984) [hereinafter Compact Interior \& Insular Affairs Subcomm. Hearing] (analysis of potential unique strategic advantages offered by Palau). 
ing World War II. ${ }^{26}$ During the war, the United States seized all islands previously under Japanese control, incurring high civilian and troop casualties. Given the high cost of liberating Micronesia and given its strategic location, some inside the U.S. government called for the outright annexation of the islands in the interest of national security. ${ }^{27}$

In 1946, President Truman rejected calls for annexation of Micronesia and instead placed the islands under the newly formed United Nations trusteeship system. ${ }^{28}$ This system, provided by chapter XII of the newly drafted U.N. Charter, ${ }^{29}$ replaced the old mandate system for administration and supervision of non-self-goverming territories. ${ }^{30}$ Under the Charter, the trusteeship system would arrange supervision for formerly mandated territories, territories detached from the nations defeated in World War II, and other territories voluntarily included by states exercising sovereignty over them. ${ }^{31}$

Truman's decision included a condition that the islands liberated from Japan be designated a "strategic trust," with the United States as the administering autlority. ${ }^{32}$ Consequently, the United Nations agreed to a separate designation for strategic trusts. ${ }^{33}$ The strategic trust would be formed under an agreement between the adininistering authority and the Security Council, rather than the General Assembly. This arrangement offered two advantages to the United States. As a permanent men1ber of the Security Council, the United States would be gnaranteed a veto over any contemplated actions. In addition, the United States gained the autlority to inake fortifications within Micronesia to contribute to the "maintenance of international peace and security." 34

The United Nations Security Council approved the Trusteeship

26. D. NeVIN, supra note 20, at 67-70.

27. The Private Papers of Senator Vandenderg 169 (A. Vandenberg ed. 1952); see also 93 CONG. REC. 87-33 (1947) (statement of Cong. Mansfield) ("I would prefer to have the United States assume complete and undisputed control of the mandates. We need these islands for our future defense, and they should be fortified wherever we deem it necessary. We have no concealed motives because we want these islands for one purpose only and that is national security. Economically they will be a liability ....").

28. Draft Trusteeship Agreement for the Japanese Mandated Islands, 2 U.N. SCOR Supp. (No. 8) (Annex 17) at 70, U.N. Doc. S/281 (1947).

29. See generally U.N. CHARTER arts. 75-85 (providing for establishment of international trusteeship system).

30. Haas, The Attempt to Terminate Colonialism: Acceptance of the United Nations Trusteeship System, 7 INT'L ORG. 1, 10-14 (1953).

31. U.N. Charter art. 77.

32. See 2 U.N. SCOR (113th mtg.) at 410 (1947) (statement of Warren R. Austin, U.S. Rep. to the United Nations).

33. Bunche, Trusteeship and Non-Self-Governing Territories in the Charter of the United Nations, 13 DEP'T ST. BULL. 1039 (1945). Articles 82 and 83 of the U.N. Charter govern strategic trusts. For a discussion of the extent and limits of the administering authority's military power within a strategic trust, see infra text accompanying notes 162-68.

34. Trusteeship Agreement, supra note 9, art. 5. 
Agreement for the Former Japanese Mandated Islands on April 2, 1947,35 and the agreement entered into force on July $18,1947 .{ }^{36}$ U.S. administration of the trust territories commenced the same day, under provisions of an executive order placing all responsibilities, on an interim basis, in the hands of the Navy Department. ${ }^{37}$ In 1951, administration of the trust territories shifted froin the Navy to the Interior Departinent. ${ }^{38}$

The Uinited Nations created a total of eleven trusteeships, ${ }^{39}$ including one strategic trust, the U.S.-administered Trust Territory of the Pacific. ${ }^{40}$ The United Nations agreed to the termination of ten of the trusteeships, allowing each of those territories to become an independent state or part of an independent state formed by the inerger of formerly dependent territories. ${ }^{41}$ Today, Micronesians are the only people still under trusteeship.

\section{U.S. Administration of the Trust Territory of the Pacific}

During the early years of the trusteeship, political and economic development progressed slowly in the Trust Territory. ${ }^{42}$ In the 1960s, however, the Micronesians began to take steps toward self-determination. The Congress of Micronesia, a legislature of the entire trust territory, first convened on the initiative of the Micronesians on July 12, 1965. ${ }^{43}$ In 1966, that Congress petitioned U.S. President Johnson to establish a cominission to promote Micronesian political development

35. S.C. Res. 21,2 U.N. SCOR Resolutions \& Decisions at 16, U.N. Doc. INF/2/REV.1 (II).

36. 8 U.N.T.S. 189, 190 n.l (1947) (codifying the Trusteeship Agreement).

37. Exec. Order No. 9875, 12 C.F.R. 4837 (1947).

38. Exec. Order No. 10265, 16 C.F.R. 6419 (1951), superseded by Exec. Order No. 11,021, 27 C.F.R. 4409 (1962), reprinted at 48 U.S.C. \$ 1681 note (1988) (administration of the Northern Marianas returned to the Navy Department until 1961, when the Department of Interior again assumed control over the entire Trust Territory).

39. These eleven trusteeships and their administrators were: Nauru and New Guinea (Australia); Ruanda-Urundi (Belgium); Cameroons and Togoland (France); Sonaliland (Italy); Western Samoa (New Zealand); Cameroons, Tanganyika, and Togoland (Great Britain); and the Trust Territory of the Pacific Islands (United States). See Clark, Self-Determination and Free Association-Should the United Nations Terminate the Pacific Islands Trust?, 21 HARV. INT'L L.J. 1, $2 \&$ n.1 (Winter 1980).

40. The Trust Territory of the Pacific Islands included all the islands in Micronesia which were formerly under Japanese inandate. Micronesia comprises three extended archipelagos: the Northern Mariana Islands, the Marshall Islands, and the Caroline Islands-the latter including the sinaller groupings of Palau, Yap, Truk, Ponape, and Kosrae. Some islands geographically within Micronesia were not under Japanese control and were not included in the Trust Territory. These include Guain, an American territory since 1898, Kiribati, which came under Britislı control in 1892 and is now independent, and Nauru, originally under Australian admimistration and now also independent. See J. Peoples, Islands in Trust: Culture Change and Dependence in MICRONESIAN ECONOMY 7-9 (1985).

41. Clark, supra note 39, at $2 \&$ nn.3-5.

42. See D. MCHEnRy, Micronesia: Trust Betrayed 12 (1975).

43. Id. at 88 . 
toward self-determination. ${ }^{44}$ Facing U.S. government inaction on the petition, the Congress of Micronesia unilaterally established the Micronesian Political Status Commission in 1967.45

The Commission's final report estabhished four principles to guide future status negotiations: (1) sovereignty should rest in the Micronesian people and their duly constituted government or governments; (2) Micronesians have the right of self-determination and may, therefore, clioose independence or self-government in free association with any nation or organization of nations; (3) Micronesians have the right to adopt their own constitution and amend, change, or revoke any constitution at any time; and (4) free association should take the form of a revocable coinpact, unilaterally terminable by either party. ${ }^{46}$

Progress toward self-determination was slow. Negotiations with the U.S. government began in September of 1969.47 During the first fornal negotiations in Washington, D.C., the Micronesian Pohtical Status Coinmission rejected a U.S. government proposal that the islands becoine a U.S. territory under article IV of the U.S. Constitution. ${ }^{48}$ The Micronesians wanted more internal autonoiny and were particularly concerned about tlie prospect of the Umited States' retaining the power of eminent domain. ${ }^{49}$

In the ensuing five years, the Trust Territory of the Pacific fraginented into four separate pohtical entities: the Cominonwealtli of the Northern Marianas, the Federated States of Micronesia, the Republic of the Marshall Islands, and the Republic of Palau. ${ }^{50}$ As a result, in 1975, the United States began negotiating separately with eacli of the political entities. Almost immediately, the Northern Mariana Islands acceded to Cominonwealth status, which was the option encouraged by the United States. ${ }^{51}$ The Northern Marianas covenant provided for self-governınent "in political uinon and under the sovereiguty of" the United States. ${ }^{52}$

In 1975, the rest of the Trust Territories held a constitutional con-

44. Id.

45. Id. at 89. Palauan Senator Lazarus Salii chaired the Commission.

46. Armstrong, The Emergence of the Micronesians Into the International Community: A Study of the Creation of a New International Entity, 5 BRoOKLYN J. INT'L L. 207, 215 \& n.27 (1979).

47. See id. at 215.

48. Id.; see U.S. CoNST. art. IV, $\S 3$, cl. 2.

49. See Armstrong, supra note 46, at 215.

50. See id. at 221; see also Compact of Free Association, June 25, 1983, United States-Marshall Islands; Umited States-Federated States of Micronesia, 99 Stat. 1800 (U.S. approval codified at 48 U.S.C. $§ 1681$ note (1988)).

51. H. NUfER, supra note 22, at 85-95. For a discussion of the negotiations of the Covenant, see Leibowitz, The Marianas Covenant Negotiations, 4 FORDHAM INT'L L.J. 19 (1980).

52. The Covenant to Establish a Commonwealth of the Northern Marianas in Political Union With the Umited States, Feb. 15, 1975, United States-Northern Mariana Islands, 90 Stat. 263 (U.S. approval codified at 48 U.S.C. $\S 1681$ note (1988)). 
vention..$^{53}$ However, a divergence in views subsequently developed among the remaining three island groups. ${ }^{54}$ The four central districts of the Carohine Archipelago-Yap, Ponape, Truk, and Kosrae-adopted the Constitution of the Federated States of Micronesia, ${ }^{55}$ but voters in both Palau and the Marshall Islands rejected it. ${ }^{56}$ The Marshall Islands later approved its own constitution in March 1979. ${ }^{57}$

\section{The Palauan Constitution}

Palau faced difficulties in drafting a constitution acceptable to the Urited States. Trouble between Palau and the administering authority arose when Palau's constitutional convention, known as the "ConCon," adopted several provisions opposed by the United States. ${ }^{58}$ The United States found two provisions particularly objectionable: the first barred the use of the eminent domain power to benefit foreign entities, and the second required the approval of three-quarters of the electorate to enter into any agreement allowing the introduction of hazardous substances, including nuclear weapons, into Palau. ${ }^{59}$

The first provision, article XIII, section 7 of the Palau Constitution, establishes that the national government "shall have the power to take

53. See Armstrong, supra note 46, at 221. In April 1978, the U.S. and Micronesian negotiators meeting in Hilo, Hawaii signed a "Statement of Agreed Principles For Free Association" to guide negotiations. These "Hilo Principles" are reprinted as an Annex to the Armstrong article. See id. at 260.

54. Id. at 221-25; see also Report of the Trusteeship Council of the Security Council on the Trust Territory of the Pacific Islands, 24 June 1977-8 June 1978, 37 U.N. SCOR Supp. (No. 1) at 73, U.N. Doc. S/12971 (1979). In 1976, Palau voted 88.5\% in support of independence from the other Trust Territory entities, A. RanNey \& H. PENNIMAN, Democracy IN THE IsLands: The Micronesian Plebiscites of 1983, at 25 (1985), but the United States initially rejected Palau's request for separate negotiations, D. MCHENRY, supra note 42, at 134.

55. Armstrong, supra note 46 , at 226-27.

56. Id.

57. Id. at 227; see MARSHALI IsLANDS CONST., reprinted in CoNSTITUTIONS OF DEPENDENCIES AND SPECIAL Sovereignties 69 (A. Blaustein \& P. Blaustein eds. 1987).

58. Initially, three separate provisions of Palau's constitution created friction with the United States. These provisions concerned (1) Palau's expansive claim of territorial waters, REPUB. OF PALAU CONST. art. I; (2) a bar ou foreign cntities benefiting from the power of emiment domain, $i d$. art. XIII, § 7; and (3) the nuclear prohibition, id. art. II, § 3, art. XIII, §6.

Article I of Palau's constitution purports to give Palau jurisdiction and sovereignty over all waters extending 200 miles from a straight archipelagic baseline "unless otherwise limited by international treaty obligations." Eventually Palauans yielded to prevailing interpretations of the Law of the Sea and accepted in an agreement with the United States much smaller territorial waters than provided in their coustitution. See Agreement Regarding the Jurisdiction and Sovereignty of the Republic of Palau Over its Territory and the Living and Non-Living Resources of the Sea, Aug. 26, 1982 (cited in Report of the United Nations Visiting Mission to Observe the Plebiscite in Palau, Trust Territory of the Pacific Islands, February 1983, 50 U.N. TCOR Supp. (No. 3) at 10, U.N. Doc. $\mathrm{T} / 1851$ (1983)).

59. Despite Legal Complications Palau Pushing Ahead With a Referendum on Constitution, Associated Press, Jnly 8, 1979 (LEXIS, Nexis library, AP file). 
property for public use upon payment of just compensation."60 It then restricts that power, stating that it "shall not be used for the benefit of a foreign entity.",61

During Palau's ConCon, a Committee on General Provisions analyzed the proposal for this provision and unanimously concluded that

[t] he power of eminent domain should not be used by either the National or State Governments for taking property for use by a foreign entity. . . . [Foreign entity shall mean] any entity whether a person, a government, a corporation, or other association or group, which is neither a citizen of [Palau] nor totally owned by citizens of [Palau]. ${ }^{62}$

Land in Micronesia has a traditional societal value that cannot be ineasured solely in economic terms, ${ }^{63}$ and consequently, the drafters of the constitution sought to keep Palauan land under Palauan ownership and control. $^{64}$

The second provision found objectionable by the United States appears in two parts of the Palau Constitution. Under article II, section 3, Palau can delegate inajor governmental powers to another state, but any agreement delegating those powers inust

be approved by not less than two-thirds (2/3) of the members of each house of the Olbiul Era Kelulau [government] and by a majority of the votes cast im a nationwide referendum conducted for such purpose, provided, that any such agreement which authorities [sic] use, testing, storage or disposal of nuclear, toxic chemical, gas or biological weapons imtended for use in warfare shall require approval of not less than threefourths $(3 / 4)$ of the votes cast in such referendum. ${ }^{65}$

Similarly, article XIII, section 6 provides that

[h]armful substances such as nuclear, chemical, gas or biological weapons imtended for use im warfare, nuclear power plants, and waste materials therefrom, shall not be used, tested, stored, or disposed of within the territorial jurisdiction of Palau without the express approval of three-

60. Repub. of Palau Const. art. XIII, $\$ 7$.

61. Id.

62. Comm. on General Provisions of the Palau Constitutional Convention, REPORT No. 30, at 4 (1979).

63. A. Ranney \& H. Penniman, supra note 54, at 4-5 (land is intimately linked to local politics, economic development and social ties).

64. Additional insight on some of the framers' related concerns can be gained from committee comments on a proposal to restrict land ownership to Palauans (referred to as "Belauans"):

The Committee feels that due to the limited amount of land in Belau and the importance of marine resources that ownership of the land and waters should be limited to citizens of Belau and corporations wholly owned by Belauan citizens. It is conceivable that unless this Constitution includes such a provision, that in the near future we will find our lands and waters under the control and ownership of non-citizens. The Committee feels that this would be destructive to Belauan society and traditions, and would also deprive Belauan citizens of many of the benefits from our natural resources.

Comm. on general Provisions of the Palau Constitutional Convention, supra note 62 , at 5-6.

65. Repub. of PalaU Const. art. II, $\S 3$. 
fourths (3/4) of the votes cast in a referendum submitted on this specific question. $^{66}$

Both provisions evince a clear intent to ban the introduction of nuclear weapons into Palau, inaking the Palauan Constitution the world's first nuclear-free constitution. ${ }^{67}$

The nuclear prohibiton first appeared in print in a proposal very similar to but less detailed than the Palau Constitution's article XII, section 7. ${ }^{68}$ The Committee on General Provisions recommended adopting the proposal to protect the environment. According to the report,

[t]he Committee felt that the environment of [Palau] . . is a public trust of which all citizens, living and yet unborn, are beneficiaries. As a trustee, [Palau] is obligated to act in a manner best calculated to assure the protection of the air, water, and other natural resources from pollution, impairment, or destruction. ${ }^{69}$

The Committee also reiterated that the proposal's purpose was to exclude hazardous substances unless voters approved a referendum on the specific issue. ${ }^{70}$

The United States immediately expressed its opposition to both these provisions. Before the Palauan ConCon conipleted work on the constitution, U.S. Ambassador Rosenblatt sent a cable with comments on the draft constitution. Among other suggestions, Rosenblatt urged that Palau drop the nuclear prohibition since it "might effectively prevent U.S. warships and aircraft from transiting Palau." "71 Rosenblatt also called on Palau to eliminate the emment domain provision because it could be "interpreted to cripple U.S. defense and security rights and responsibilities."72

The ConCon annended the draft constitution to conform to a number of Ambassador Rosenblatt's suggestions but did not reinove the elminent doinain or nuclear prohibition provisions. ${ }^{73}$ The Palau District Legislature, however-reportedly acting under U.S. pressure-nullified

66. Id. art. XIII, § 6.

67. See Associated Press, supra note 7.

68. See Palau Constitutional Convention, Constitutional Proposal No. 91 (1979).

69. Comm. on General Provisions of the Palau Constitutional Convention, REPORT No. 29, at 1-2 (1979).

70. See id. at 2 .

71. Cable from Ambassador Rosenblatt to Roman Tmetuch1, sec. 3, at 5 (March 22, 1979).

72. Id. at 6.

73. The U.S. warned in the Rosenblatt Cable of the potential effect of the draft language. See Cable from Ambassador Rosenblatt to Roman Tmetuchl, sec. 3 at 5.6 (March 22, 1979). The ConCon records show that the Palau Constitutional Drafting Commission responded affirmatively to certain suggestions in Ambassador Rosenblatt's cable, for example, by deleting language allowing government restrictions on the freedom of the press in the subsequent draft of the constitution. See Palau Constitutional Drafting Commission, Report to the Palau legislature, app. at 5 (1979). 
the draft constitution and canceled the scheduled July plebiscite. ${ }^{74}$ Nonetheless, as a result of a lawsuit filed by supporters of the constitution, the July plebiscite went ahead and $92 \%$ of the electorate voted in favor of the constitution. ${ }^{75}$ The High Court of the Trust Territories, however, refused to certify the results because of the nullifying legislation. ${ }^{76}$

The Palau Constitutional Drafting Commission consequently redrafted the Palau Constitution with the " 'expressed intent' of accoininodating U.S. interests." 77 The revised constitution deleted the nuclear prohibition language froin article II, and anended article XIII, section 6, to exeinpt "transit and port visits of ships, and transits and overflights of aircraft."78 The Commission also struck the restriction on who could benefit from the power of eminent doinain. ${ }^{79}$

This revised constitution, deemed compatible with the U.S. assessment of its "defense and security rights," The Palauans soundly rejected the U.S.-approved constitution, with 70\% voting no. ${ }^{81}$ A third election followed, with the original nuclear prohibition and limitations on the power of eminent domain reinstated into the constitution. On July 17, 1980, Palauans adopted the "nuclear-free" constitution with $79 \%$ of the electorate voting their approval. ${ }^{82}$ The three votes (two overwhelmingly approving the nuclear prohibition and eminent doinain provisions and one rejecting a softening of these provisions), the plain ineaning of the language of the Palau Constitution, and the legislative history lead to one conclusion: Palauans, in a reinarkable display of electoral consensus, expressly chose to adopt very strong constitutional bans on nuclear weapons and the use of the power of eminent domain to benefit foreign states.

\section{E. The Compact of Free Association}

After the adoption of a constitution, the next and final step toward sovereignty was to negotiate an agreeinent with the adıninistering authority, the Umited States. In 1980, the three Micronesian entities still under trusteeship-Palau, the Marshall Islands, and the Federated States

74. See R. Clark \& S. Roff, Micronesia: The Problem of Palau 8 (Minority Rights Group Report No. 63, 2d ed. 1987).

75. Id.

76. Id.

77. People of Palau Try to Win American Approval With Second Draft Constitution, Associated Press, Oct. 21, 1979 (LEXIS, Nexis library, AP file).

78. See Palau Constitutional Drafting Commission, Report to the palau LEgISLATURE, app. at 29 (1979).

79. See id., app. at 30 .

80. Id., app. at 3 .

81. R. ClARK \& S. RoFF, supra note 74 , at 8.

82. Associated Press, supra note 7. 
of Micronesia-initialed the Compact of Free Association, a document containing the basics of an agreement for their future relationship with the United States. ${ }^{83}$ The change in U.S. administrations in 1981, however, delayed the progress of Micronesian status negotiations. ${ }^{84}$ By the tinie negotiations resumed, the interests of each of the three island groups had diverged. ${ }^{85}$ As a result, the Reagan administration began to negotiate with each entity separately. ${ }^{86}$

The original Compact, initialed in 1980, provided that the United States would have responsibility for Micronesian security and defense matters for fifteen years, with specific military operational rights to be set forth in separate agreements with each entity. ${ }^{87}$ Palau's constitutional restriction on the power of eminent doinain and on the introduction of nuclear material conflicted with the U.S. interpretation of those rights; ${ }^{88}$ these conflicts coinplicated the Coinpact approval process in Palau.

Palau's first plebiscite on the Coinpact of Free Association took place on February 10, 1983. ${ }^{89}$ The ballot mcluded two questions: (1) Do you approve of Free Association as set forth in the Compact of Free Association? (2) Do you approve of the Agreement concerning radioactive, chemical, and biological materials concluded pursuant to section 314 of the Compact of Free Association? ${ }^{90}$ The two questions received affirmative votes of $61 \%$ and $51 \%$, respectively. ${ }^{91}$

83. Armstrong, Strategic Underpinnings of the Legal Regime of Free Association: The Negotiations for the Future Political Status of Micronesia, 7 BROOKLYN J. INT'L L. 179, 183-84 (1981). Under "free association" the trust territories would become sovereign states but would cede certain powers primarily dealing with defense and defense-related foreign affairs to the United States. Id.

84. The Reagan administration reviewed the initialed version for several nonths before accepting it. Micronesian Status Negotiations: Hearing Before the Subcomm. on East Asian and Pacific Affairs of the Senate Comm. on Foreign Relations, 97th Cong., 2nd Sess. 3 (1982) (statentent of Fred M. Zeder II, U.S. Ambassador and President's Personal Rep. for Micronesian Status Negotiations).

85. Armstrong \& Hills, The Negotiations for the Future Political Status of Micronesia, 78 AM. J. INT'L L. 484, 487 (1984).

86. Id. at $487-88$.

87. Id. at 486 .

88. See id. at $487-88$.

89. A. Ranney \& H. Penniman, supra note 54, at 27.

90. See Koshiba v. Remeliik, No. 17-83, slip op. at 66-67 (Palau Sup. Ct., Trial Div., Jan. 31, 1983). The opinion summarizes events related to a divisive controversy over ballot language originating in a cable front Ambassador Fred M. Zeder II, the U.S. President's Personal Representative for Micronesian Status Negotiations, to Ambassador Lazarus Salii of Palau. Citizens of Palau brouglit a suit challenging the language because it wrongly implied that a pro-Compact vote would restrict the U.S. military. A justice of the Palau Suprene Court enjoined the ballot language, holding that its use would deny the plaintiffs their constitutional voting rights. Id. at 72 .

91. Report of the United Nations Visiting Mission to Observe the Plebiscite in Palau, Trust Territory of the Pacific Islands, February 1983, 50 U.N. TCOR Supp. (No. 3) at 38, U.N. Doc. T/ 1851 (1983); see also Gibbons v. Salii, App. No. 101-86, shp op. at 2 n.1 (Palau Sup. Ct., App. Div., Sept. 17, 1987). 
Following the announcement of the results, the U.S. State Department declared the Compact approved in " 'a valid and sovereign act of self-determination by the people of Palau." "92 Despite the claim of victory for the Compact, the United States also demanded separate assurances from the government of Palau that, under its constitution, the Umited States would have the authority to bring nuclear weapons into Palau. ${ }^{93}$ Meanwhile, Palauan opponents of the Compact filed suit challenging the approval, arguing that the constitution prohibited the United States from carrying nuclear weapons into Palau. ${ }^{94}$ The Palau Supreine Court upheld their challenge, concluding that the Compact had not passed by the $75 \%$ margin required under the constitution's nuclear control provisions. ${ }^{95}$

Ambassador Fred M. Zeder II, the U.S. President's Personal Representative to the Micronesian Status Negotiations, disagreed with the court's decision. He sent a cable to Palau's negotiator, Ambassador Lazarus Sahi, in which he reiterated the U.S. position that the vote had satisfied the legal requirements for the Compact's approval. ${ }^{96}$ According to Ambassador Zeder, the vote was sufficient to demonstrate that the United States had fulfilled its obligation to guarantee Palauans their right of self-determination. ${ }^{97}$ The Umited States thereby adopted the view that after the 1983 plebiscite, any concerns over self-determination in Palau had becoune "an internal problem." 98

Over the next two years, the Palauans atteinpted to negotiate an agreement acceptable to both the U.S. government and the Palauan citizens. In September 1984, Palauans voted again on a modified but substantially similar version of the Compact. ${ }^{99}$ The $67 \%$ affirinative vote in

92. Reuters, Feb. 18, 1983 (quoting U.S. Dep't of State announcement) (LEXIS, Nexis library, Reuters file).

93. See Armstrong \& Hills, supra note 85, at 488 \& n. 17 (citing Letter from Ambassador Fred M. Zeder II, the President's Personal Representative for Micronesian Status Negotiations, to Palauan President Haruo I. Remeliik (April 21, 1983)).

94. See Gibbons v. Remeliik, 1 Repub. of Palau Intrm. 80, 81 (No. 67-83) (Palau Sup. Ct., Trial Div., Aug. 6, 1983).

95. Id. at 82 .

96. See R. ClARK \& S. RoFF, supra note 74, at 17.

97. Id. Ambassador Zeder attempted to clarify the U.S. position in a letter several months later to the Palau Senate. In the letter, Zeder insisted tliat the nullified plebiscite was a "valid act of self-determination in the international context of the Trusteeship Agreement and as an approval of the compact." See Letter from Ambassador Fred M. Zeder II to Mr. Peter L. Sugiyam, Senate, First Olbiil Era Kelulau (Oct. 25, 1983), reprinted in 51 U.N. TCOR Annex (Sess. Fas.) at 18, U.N. Doc. T/1861 (1986).

98. Compact Interior \& Insular Affairs Subcomm. Hearing, supra note 25, at 13 (statement of Ambassador Fred M. Zeder II) ("The problem . . that [the Palauans] have is making tlieir compact and the constitution compatible .... They drafted their own constitution. We look on this as an internal problem that their constitutional government las to come to grips with.").

99. See A. RANNEY \& H. PenNiman, supra note 54, at 49-50 (describing the main alteration as a deletion of any "explicit reference to the storage or transslipment of nuclear materials"). 
this second Compact referendum was again insufficient to meet the constitutionally required three-quarters majority. ${ }^{100}$ In contrast, between the two Palauan plebiscites, voters im both the Federated States of Micronesia and the Marshall Islands approved their Compacts of Free Association with the United States. ${ }^{101}$

On June 30, 1985, Palau's President Haruo Remeliik was assassinated, ${ }^{102}$ and the identity and motive of the assassins remain a mystery to this day. ${ }^{103}$ Within two months of the assassmation, Lazarus Salii, the veteran political negotiator, was elected Palau's second president. ${ }^{104}$ On January 10, 1986, Salii and President Reagan signed the third and latest version of the Compact. ${ }^{105}$ The preamble of that version declares that with the adoption of a constitution and the "entry of their Government into this Compact of Free Association," the Palauan peoples will exercise their "sovereign right to self-determination."106 The relevant provisions of that Compact are discussed below. ${ }^{107}$

Title I of the Compact defines the general structure of relations between the two governments under the Coinpact, including tle division of authority. It declares that the people of Palau are self-governing, ${ }^{108}$ and establishes that Palau lias the capacity to conduct foreign relations within certain parameters. ${ }^{109}$ In addition, it provides that the United States assumes no responsibility for the actions of Palau's government unless otherwise expressly approved. ${ }^{110}$

Title I also governs those aspects of the bilateral relationship involving enviroumental protection in Palau. ${ }^{111}$ Under tliese provisions, the United States pledges during trusteeship to apply standards "substantially similar" to those required under the National Enviroumental

100. See Repub. Of Palau Const. art. II, \$ 3.

101. See A. Ranney \& H. Penniman, supra note 54, at 49. Ranney and Penniman's book provides a detailed account of all three plebiscites, written by a group of observers under U.S. Information Agency sponsorship. See id. at xi (President's Foreword). The Federated States of Micronesia recorded a 79\% affirmative vote for the Compact. Id. at 72. In the Marshall Islands, $58 \%$ of the electorate voted approval. Id. at 103. In January 1986, the U.S. Congress approved those Compacts of Free Association. See Pub. L. No. 99-239, 99 Stat. 1770 (codified as amended at 48 U.S.C. § 1681 note (1988)).

102. N.Y. Times, Nov. 27, 1986, at A18, col. 1.

103. Rampell, Assassination in Palau, Honolulu MaG., Aug. 1987, at 44 (motives and murderers still unknown); N.Y. Times, July 21, 1987, at A16, col. 1 (describing appellate court acquittal of the three men convicted of the assassination).

104. N.Y. Times, Sept. 2, 1985, at A5, col. 5.

105. Leich, Contemporary Practice of the United States Relating to International Law, 81 AM. J. INT'L L. 405, 408 (1987).

106. Compact of Free Ass'n, supra note 1, preamble.

107. See infra text accompanying notes 108-21.

108. See Compact of Free Ass'n, supra note 1, tit. I, art. I, $\S 111$.

109. See id. tit. I, art. II, § 121 .

110. See id. §§ 126, 127.

111. See id. art. VI. 
Policy Act. ${ }^{112}$ The environmental protection provisions, however, contain an escape clause for the U.S. military. Under this clause, the U.S. President may exempt any U.S. government activities im Palau from these provisions "if the President determines it to be im the paramount imterest of the Government of the Umited States to do so" under either mternational law or the Compact's security and defense provisions. ${ }^{113}$

Title III of the Compact structures "security and defense relations" between Palau and the Umited States. ${ }^{114}$ Article 1 of title III provides for the following:

(A) Section 311 establishes that Palau is to be closed to all foreign militaries except that of the United States, except as provided in section $312 ;^{115}$

(B) Section 312 specifies that the U.S. "lias full authority and responsibility for security and defense matters" in Palau and thus may imvite the armed forces of other nations into Palau; ${ }^{116}$

(C) Section 313 coinpels Palau to refrain from actions which the United States determines to be "incompatible with its authority and responsibility for security and defense matters." 117

Article II of title III of the Conipact provides for "Defense Sites and Operating Riglits."118 Sections 321 and 322 of that article direct the government of Palau to make land and water areas designated "defense sites" by the Umited States available to the United States "for the dura" tion and level of use specified."119 Section 324 provides that althougl the Umited States cannot "use, test, store or dispose of nuclear, toxic chemical, gas or biological weapons" in Palau, the United States can operate "nuclear capable or nuclear propelled vessels and aircraft witlin the jurisdiction of Palau witlout either confirming or denymg the presence or absence of such weapons."120

112. Id. § 163 .

113. Id.

114. Id. tit. III.

115. Id. art. I, § 311.

116. Id. $\S 312$.

117. Id. §313; see also Clark, supra note 39, at 26-27. Professor Clark postulates that this "defense veto" (which remains essentially unchanged in the current version of the Compact) would allow the United States to prevent Palau from assigning fishing rights to third-party states or even to build an agricultural warehouse with foreign financing. Id. at 26.

118. Compact of Free Ass'n, supra note 1, tit. III, art. II.

119. Id. art. I, $\S 321,322$. This provision, and the provisions of section 324, see infra text accompanying note 120 , seen to conflict with the eminent domain and nuclear prohibition provisions of the Palau Constitution. The Palau Supreine Court agreed. See infra text accornpanying notes $126-30$.

120. Id. § 324. According to Ambassador Zeder, the intent of this revised provision was to "ensure compatibility between the Compact and Palau's constitution" without impairing the "ability of the U.S. to carry out fully [its] defense role." The Compact of Free Assaciation Between the United States and Palau: Hearings on H.R.J. Res. 626 Before the House Comm. on Foreign Affairs, 99th 
Title IV contains the termination and survivability provisions. Although Palau unay terminate the Compact by a majority vote in a plebiscite, certain provisions, including all of title III, "shall remain in full force and effect" until the fiftieth anniversary of the effective date of the Compact. ${ }^{121}$ In essence, for fifty years, Palau under the Compact cannot avoid certain obligations to the United States, primarily those involving security and defense matters under title III, without U.S. consent.

On February 21, 1986, the third version of the Compact received a 72\% affirmative vote in Palau's third plebiscite. ${ }^{122}$ Three days later, President Salii certified the results and declared the Compact approved. ${ }^{123}$ The Uinited States accepted Salii's certification of the vote, taking the position that $75 \%$ approval was no longer required in hight of the Compact revisions. ${ }^{124}$ On its face, however, the revised Coinpact failed to satisfy both the total nuclear prohibition and the eminent domain provisions of the Palau Constitution; the Compact would still permit botlı offending practices.

Supporters of Palau's Constitution challenged Salii's approval of the Coinpact, and in Gibbons v. Salii, the Palau Supreme Court held that the Constitution was "supreme in Palau" and that the new version of the Coinpact, like its predecessors, would require a $75 \%$ affirmative vote for approval. ${ }^{125}$ According to the court, the nuclear prohibition in the Palau Constitution applied to the transit of nuclear-capable and nuclear-powered ships. ${ }^{126}$ The Compact, even in its revised form, permitted such transit. ${ }^{127}$ Therefore, the Compact revisions failed to resolve the conflict between that agreement and the Palau Constitution.

The Gibbons v. Salii court also considered whether Palau's

Cong., 2d Sess. 76-77 (1986) [hereinafter Hearings on H.R.J. Res. 626, Compact of Free Association] (statement of Fred M. Zeder II, U.S. Ambassador and President's Personal Rep. for Micronesian Status Negotiations).

121. Coinpact of Free Ass'n, supra note 1, tit. IV, art. V, $\S \S 452,453$.

122. Hearings on H.R.J. Res. 626, Compact of Free Association, supra note 120, at 75 (stateinent of Ambassador Zeder).

123. Id. at 66 (statement of Ambassador Zeder).

124. Id. at 77-78 (stateinent of Ambassador Zeder).

125. Gibbons v. Salii, App. No. 8-86, slip op. at 22, 27 (Palau Sup. Ct., App. Div., Sept. 17, 1986). At the trial court level, the court offered insights into its futile searcl for legal authority to uploold the Coinpact. Justice Gibson stated:

It is patent that the intent of the Constitntional Convention delegates was to inake it wellnigh impossible to, as the Plaintiffs say, over-ride the Constitntion. Each and every source to which I turned for help in endeavouring to find validity for the Coinpact, confirmed a contrary intent and the unarguable conclusion that it was the intention of the delegates to make ... Palau forever nuclear-frce. ... [I]t follows of natural consequence that all things sounding of nnclear warfare, including nuclear-propelled and nuclear-capable vessels are forbidden to transit, enter, or port in the Palauan waters.

Gibbons v. Salii, No. 101-86 (Palau Sup. Ct., Trial Div., July 10, 1986) (oral opinion) (quoted in R. CLARK \& S. ROFF, supra note 74, at 20).

126. Gibbons v. Salii, App. No. 8-86, slip op. at 22-23.

127. See supra text accompanying note 120 . 
obligations to supply land to the U.S. military under sections 321 and 322 of the Compact could be reconciled with the constitutional restriction against using the power of eminent domain for the benefit of a foreign entity. The court held that because the Compact does not itself require the exercise of the power, the provisions were not unconstitutional on their face and the issue was not ripe for adjudication. ${ }^{128}$ Nevertheless, the court found that the provisions raised "the specter of future constitutional crisis" ${ }^{129}$ and gave the following admonition:

[W] caution the government of Palau that the exercise of eminent domain powers will be unavailable to it in attempting to comply with its obligations under the Compact to make land available to the United States. We suggest that this Compact section be carefully evaluated before further steps are taken to obtain Compact approval. ${ }^{130}$

Despite the Palau Supreme Court's invalidation of the Compact, the U.S. Congress voted to approve that saine document on November 14, 1986. ${ }^{131}$ The congressional act authorized the U.S. President to inplement the Compact following approval by Palau, and to take into account "any procedures with respect to the United Nations for termination of the Trusteeship Agreement."132

With encouragenent by President Salii, Palau subsequently held two plebiscites on the sanie version of the Compact. In both votes, the Compact again failed to inuster the required $75 \%$ approval. ${ }^{133}$ Following this fifth failure to approve the Conupact, financial and political tensions erupted in Palau. Faced with large budget deficits, and indebted to the United States for nuoney advanced for political education campaigns counected with the plebiscites, President Salin announced a fiscal einergency. ${ }^{134}$ In an attempt to reduce government expenditures, Salii furloughed 900 of Palau's 1,331 government employees, thereby putting $40 \%$ of the Palauan workforce out of work. ${ }^{135}$

128. Gibbons v. Salii, App. No. 8-86, slip op. at 36.

129. Id. at 29.

130. Id. at 37.

131. See Compact of Free Association Between Umited States and Government of Palau, Pub. L. No. 99-658, 100 Stat. 3672 (1986) (codified as amended at 48 U.S.C. § 1681 (1988)).

132. Id. § $101(\mathrm{a}), 100$ Stat. at 3673 .

133. In the December 2, 1986 plebiscite, with a turnout of over $80 \%$ of the Palauan electorate, $66 \%$ of the votes were cast in favor of the Compact. Report of the United Nations Visiting Mission to Observe the Plebiscite in Palau, Trust Territory of the Pacific Islands, December 1986, 54 U.N. TCOR Supp. (No. 1) at 13-14, U.N. Doc. T/1906 (1987). In the June 30, 1987 plebiscite, the affirmative vote was only sliglitly ligher: $68 \%$. Report of the United Nations Visiting Mission to Observe the Plebiscite in Palau, June 1987, 54 U.N. TCOR Supp. (No. 2) at 9, U.N. Doc. T/1919 (1987).

134. See W. Butler, G. Edwards \& M. Kirby, Palau: A Challenge to the Rule of LAW IN MICRONESIA 29-31 (1988) (report to the International Commission of Jurists); see also Letter from Ricliard T. Montoya, Ass't Sec'y for Territorial and Int'l Affairs, United States Dep't of Interior, to President Salii (Nov. 6, 1988) (declining Salii's request for the United States to underwrite "political education," but offering a $\$ 250,000$ advance on future funds).

135. W. BUTLER, G. EDWARDS \& M. KIRBY, supra note 134, at 30-31. 
The furloughed workers formed a committee demandimg ratification of the Compact. ${ }^{136}$ The Olbiil Era Kelulau (OEK) (the legislative body of Palau), under threats of violence from an armed mob, approved legislation calling for two new referenda: one to amend the constitution to allow for simple majority approval of the Compact, the second to vote on the Compact. ${ }^{137}$ On August 4, 1987, 73.3\% of Palauan voters favored an amendment to the Palau Constitution which would alter the majority required to approve the Compact from $75 \%$ to a simple majority. ${ }^{138}$ As a result, a seventh Compact plebiscite was held on August 21, 1987, and it attained a nearly identical affirmative vote. ${ }^{139}$

Three supporters of the Palau Constitution, led by Ibedul Gibbons, a traditional chief, challenged the constitutional amendment and Compact approval process. ${ }^{140}$ But before the case could be heard, Ibedul Gibbons and President Salii signed a "Memorandum of Understanding," which resulted in dismissal of the suit. ${ }^{141}$ Essentially, the memorandum gave the Palauan President the right to cede lands to the United States, but only with the approval of the traditional council of chiefs. ${ }^{142}$

Within two days of the dismissal, a group of Palauan women elders filed a new suit to challenge the Compact approval. ${ }^{143} \mathrm{~A}$ wave of violence and threats directed at those plamtiffs and the court ensued. ${ }^{144}$ Following these imcidents, police officers drove to the plaintiffs' honies and secured signatures on a Stipulation of Dismissal. ${ }^{145}$ Although Judge Robert A. Hefner of Palau's Supreme Court accepted the dismissal on September 9, 1987, 146 in his opimion he observed that "the Dismissal

136. Id. at 31-32 \& n.2.

137. Id. at $32-35$.

138. Report of the United Nations Visiting Mission to Observe the Plebiscite in Palau, August 1987, 54 U.N. TCOR Supp. (No. 3) at 3, U.N. Doc. T/1920 (1987).

139. Id. at 8.

140. See Merep v. Salii, No. $139-87$ (Palau Sup. Ct., Trial Div., filed 1987) (dismissed per stipulation, Aug. 28, 1987), discussed in Fritz v. Salii, No. 161-87, slip op. at 5 (Palau Sup. Ct., Trial Div., April 22, 1988), aff'd, App. No. 8-88 (Palau Sup. Ct., App. Div., Aug. 29, 1988); see also Recent Developinents, 29 HARV. INT'L L.J. 149, 156 \& n.42 (1988) (discussing Merep).

141. Fritz v. Salii, No. 161-87, slip op. at 5, 8-10 (reviewing court file in Merep); Recent Developments, supra note 140 , at 156 \& n.43.

142. Recent Developinents, supra note 140, at 156 n.43. However, the Salii-Gibbons agreement may be of questionable legal validity. See id. (citing 2 PAC. NEws Bull. 1 (1987)).

143. See W. BuTler, G. EdWARdS \& M. KIRBY, supra note 134, at 39.

144. See id. at $39-42$ (describing power outage in Palau's capital city, Koror, threats to the plaintiffs, murder of the main plaintiff's father, fire-boinbing of the main plaintiff's loouse, slots fired at the loines of a plaintiff and tlie speaker of the House, and mobs that surrounded the court deinanding the disinissal of the case).

145. Id. at 42 .

146. See Ngirmang v. Salï, No. 161-87, (Palau Sup. Ct., Trial Div., filed Aug. 31, 1987), withdrawn, (Palau Sup. Ct., Trial Div., mein. op. Sept. 9, 1987), reinstated sub nom. Fritz v. Salii, No. 161-87, (Palau Sup. Ct., Trial Div., Mar. 31, 1988), affd, App. No. 8-88 (Palau Sup. Ct., App. Div., Aug. 29, 1988). 
signed by Plaintiffs may not be voluntary. There are indications that the Dismissal was brought about by intimidation through the use of violence." 147

On November 30, 1987, the Reagan administration formally asked Congress to enact the Compact. ${ }^{148}$ With the constitutionality of Palau's approval still in doubt, however, the U.S. Congress was reluctant to give its final imprimatur. ${ }^{149}$

The original plaintiffs in Ngirmang v. Salii later decided to petition to reinstate their challenge to the Augnst 21 vote approving the Compact. ${ }^{150}$ In April 1988, the lower court set aside the dismissal and ruled for the plamtiffs, holding that the August 4, 1987 referendum on the constitutional ainendment was "null, void and of no effect"; 151 consequently, the August 21 vote was insufficient to approve the Coinpact. That decision was affirmed by the Appellate Division of Palau's Supreine Court on August 28, 1988, 152 eight days after President Salii died at home from a gunshot wound, in a possible suicide. ${ }^{153}$ Thus, the legislature failed to circumvent the constitutional requirement of a $75 \%$ voter approval of the Compact.

In the wake of the sixth rejection of the Compact in Palau, U.S. congressional efforts to pass a "Palau Bill" as a signal of American approval of the Coinpact stalled. ${ }^{154}$ Rather than concede to military

147. Ngirmang v. Salii, No. 161-87, mem. op. at 1-2.

148. End-of-Session Tempest Leaves Palau Twisting, CoNg. Q. WEEkLY REP., Nov. 26, 1988, at 3399 (recounting history of Palau independence legislation in Congress).

149. See N.Y. Times, Oct. 13, 1987, at A19, col. 1.

150. See Fritz v. Salii, No. 161-87, slip op. at 6-7.

151. Id. at 33 .

152. Fritz v. Salii, App. No. 8-88, slip op. at 25-26 (Palau Sup. Ct., App. Div., Aug. 29, 1988). The court again made note of the intent of the drafters "to provide a rigid bar to larmful substances being introduced into Palau." Id. at 3 \& n.2. The court's narrow ruling left open the possibility of amending the Palau Constitution to ease approval of the Compact. See Letter from J. Edward Fox, Ass't Sec'y for Leg. Affairs, U.S. Dep't of State, to Hon. J. Bennett Johnson, Chairman of the Senate Comm. on Energy and Natural Resources (Sept. 14, 1988) (interpreting the Palau Supreme Court Appellate Division's ruling in Fritz v. Salii to permit amendment of Palau's Constitution in order to approve the Compact as drafted).

153. N.Y. Times, Aug. 21, 1988, at 23, col. 1. Apparently, Salï lad received a series of bad news reports. For one, lie liad just learned that the General Accounting Office was pursuing an investigation into corruption charges against him. See Wasl. Post, Sept. 6, 1988, at A26, col. 1. Salii lad also just learned that a federal court had ruled that Palau must repay a $\$ 45$ million debt on the IPSECO power plant. Id.

In addition, Salii had been deeply troubled over the stalled Counpact approval process. In February of 1988, while Compact opponents prepared their legal challenge, Salii wrote U.S. Seeretary of State George Slultz decrying the "turmoil which affects Palau as our people wait from day to day in wonder, frustration and consternation that the wishes of an overwhehning majority are leld captive by the few who, for whatever motivation, would prolong our torment." See Hearings on H.R.J. Res. 479, Compact of Free Association, supra note 21, at 109 (statement of Hon. Lazarus E. Salii, President, Repubhic of Palau).

154. See generally End-of-Session Tempest Leaves Palau Twisting, CoNG. Q. WeEkLY REP., Nov. 26, 1988, at 3398 . 
restrictions in Palau, U.S. officials in the executive branch continued to urge Palauan approval of the Compact as written. ${ }^{155}$

In November 1988, Palauans elected as their president Ngiratkel Etpison, ${ }^{156}$ who while campaigning had declared his strong support for the Coinpact of Free Association with the United States. ${ }^{157}$ After taking office in January, however, Etpison signaled his approval of a unified position adopted by the leadership of Palau's OEK, stating that conflicts between the Palau Constitution and the Compact inust be resolved with changes to the Compact, not to Palau's Constitution. ${ }^{158}$

In the face of a U.S. government adamant about maintaining unchallengeable rights of transit for nuclear vessels and eminent domam for military bases, however, ${ }^{159}$ the Palauan resolve to change the Compact quickly disintegrated, and instead Palau held a seventh vote on the Compact of Free Association on February 6, 1990. This vote once again failed to achieve the required three-quarters majority, and, significantly, support for the Compact dropped from $73 \%$ of votes cast (during the August 1987 referendum) to just over $60 \%{ }^{160}$ Nevertheless, a U.S. State Department official again indicated that the United States would not renegotiate the Compact to eliminate the provisions in conflict with Palau's Constitution. ${ }^{161}$

155. See, e.g., Letter from James D. Berg, Dir. Office of Freely Assoc. State Affairs, U.S. Dep't of State, to the Hon. Thomas Remengesau, Pres. of the Republic of Palau (Sept. 22, 1988) (expressing United States readiness to implement the Compact promptly upon approval).

156. L.A. Times, Nov. 12, 1988, at 11, col. 1. The margin of Etpison's victory was only 31 votes out of 9,000 total ballots cast. Id.

157. Id, see also L.A. Times, Feb. 12, 1989, at 29, col. 1 (stating that Etpison "pledged to push for domestic self-rule while allowing the United States to continue to control Palau's defense and foreign policies").

158. See Position Statement on the Future Pohitical Status of Palau, 3d Olbiil Era Kelalau (Jan. 16, 1989); see also Letter from Hon. Ngiratkel Etpison, Pres. of the Republic of Palau, to the Hon. Shiro Kyota, House Speaker (Jan. 17, 1989) (transmitting a bill for an act to create a commission on the future of relations witl the United States, which wonld adhere to the Position Statement adopted by the OEK).

159. See Palau Compact of Free Association Implementation Act: Hearing on H.R.J. Res. 175 Before the Senate Comm. on Energy and Natural Resources, 101st Cong., 1st Sess. 30 (1989) (statement of Philip E. Barringer, Ass't Sec'y of Defense for Int'1 Security Affairs, Dep't of Defense). Mr. Barringer expressed Defense Department approval of the Compact, indicating that it serves "U.S. national security interests" because:

1. It provides for demial of Palauan territory to unfriendly forces;

2. It ensures freedom of operation for U.S. nuclear-propelled and U.S. nuclear-armed ships and aircraft in Palauan territorial waters and airspace;

3. It preserves U.S. policy of neither confirming nor denying the presence or absence of nuclear weapons at a specific location;

4. It preserves the U.S. rigltt to establish and use defense sites in Palau. Id.

160. Report of the United Nations Visiting Mission to Observe the Plebiscite in Palau, Trust Territory of the Pacific Islands, February 1990, 57 U.N. TCOR Supp. (No. 1) at 10, U.N. Doc. T/ 1942 (1990); see also L.A. Times, Feb. 11, 1990, at 10, col. 3.

161. See South Pacific: Another "No" to U.S. Terms in Palau?, Inter Press Service, Feb. 9, 1990 
II

\section{UNITED STATES Violation OF THE TERMS OF Trusteeship AgreEMENT}

A major objective of the trusteeship system, as set forth in article 76 of the U.N. Charter, is "to further international peace and security."162 But the United States also claims certain exceptional military rights in Palau under the Trusteeship Agreement of 1947, the agreement that estabhished the basis for the legal relationship between the United States and Palau. Article 5 of that agreeinent authorizes the Umited States to estabhish bases, erect fortifications, station and einploy armed forces, and make use of volunteer forces and facilities in the territory. ${ }^{163}$ After submitting the first draft of the agreement to the Security Council, the U.S. Representative declared that the "purpose is to defend the security of these islands in a nuaimer that will contribute to the building up of genuine, effective and enforceable collective security for all Menibers of the United Nations." 164

When the United States acquired these security rights, however, it also accepted a range of obhigations to the trust territories. Under article 6 of the Trusteeship Agreenient, the United States is responsible for promoting the economic, political, social, and educational advancenient of the inhabitants. ${ }^{165}$ Although the Trusteeship Agreement offers scant criteria upon which to evaluate U.S. performance in Palau, ${ }^{166}$ the U.N. Security Council could momitor and enforce U.S. performance using

(LEXIS, Nexis library, Inpres file) (quoting a U.S. State Department official as saying that "the offer [of the Free Association] remains valid and we hope that ... we could conclude the deal").

162. U.N. Charter art. 76(a).

163. See Trusteeship Agreement, supra note 9, art. 5. Judge McNair described the mandate and trusteeship systems as follows:

The Mandates System (and tle 'corresponding principles' of the International Trusteeship System) is a new institution-a new relationship between territory and its inhabitants on the one liand and the government which represents them internationally on the other. ... The doctrine of sovereignty lias no application to this new system. Sovereignty over a Mandated Territory is $m$ abeyance; if and when the inhabitants of the Territory obtain recognition as an independent State . . s sovereignty will revive and vest in the new State. What matters . . . is not where sovereignty lies, but what are the rights and duties of the Mandatory in regard to the area of territory being administered by it. The answer to that question depends on the international agreements crcating the system and the rules of law which they attract. Its essence is that the Mandatory acquires only a limited title to the territory entrusted to it, and that the measure of its powers is what is necessary for the purpose of carrying out the Mandate.

International Status of South-West Africa, 1950 I.C.J. 128, 150 (July 11, 1950) (McNair, J., separate op.).

164. 2 U.N. SCOR (113th mtg.) at 410 (1947) (statement of Warren R. Austin, U.S. Rep. to the United Nations).

165. See Trusteeship Agreeunent, supra note 9, art 6.

166. See, e.g., H. NUFER, supra note 22 (sociological evaluation of U.S. administration of the trust territories over the first three decades against the goals set fortl in article 6 of the Trusteeship Agreement). 
these objectives. ${ }^{167}$

Of the four responsibilities, the obligation to promote political development toward self-government is the most crucial to self-determination. ${ }^{168}$ But each of the other responsibilities, and particularly tlie obligation to promote economic development toward self-sufficiency, is also essential to self-determination. Therefore, the next two Sections of this Comment briefly examine economic and political development in Palau as eacli relates to U.S. performance under the Trusteeship Agreement and Palau's riglit to self-determination.

\section{A. Economic Advancement Under U.S. Administration}

The Trusteeship Agreement includes basic criteria for an assessment of the requisite economic development. Under the agreement, the United States is responsible for fostering economic self-sufficiency througli such measures as the development of fisheries, agriculture, and industries; the Umited States is also responsible for protecting tlie inhabitants against the loss of land and resources. ${ }^{169}$

U.S. administration of Palau lias been characterized by two approaches to economic policy, neitlier of whicls advances the goals of the Trusteeship Agreement. In the early years, the United States neglected economic developnent. A 1959 U.N. Visiting Mission report on territory-wide economic problems attributed slow development to an inadequate cominitment of funds. ${ }^{170}$ The Kennedy administration, in contrast, created the full-blown Pacific welfare states. While a welfare

167. MacDonald, Termination of the Strategic Trusteeship: Free Association, the United Nations and International Law, 7 BROOKLYN J. INT'L L. 235, 253 (1981). The Trusteeship Agreement offers scant criteria upon which to evaluate U.S. performance in this regard. An evaluation might take the following form:

[I]n determining whether the United States, as administering authority, had met its obligations, an examination of the political, economic, social and educational advancement of the people of the territory and their progress toward self-government or independence might be appropriate matters of inquiry. Similarly, the basis for discussion might focus Id. upon the more specific obligations undertaken in Article 6 of the Trusteeship Agrecment.

168. Id.

169. Article 6 states that the administering authority shall

[p]romote the economic advancement and self-sufficiency of the inhabitants, and to this end shall regulate the use of natural resources; encourage the development of fisheries, agriculture, and industries; protect the inhabitants against the loss of their lands and resources; and improve the means of transportation and communication.

Trusteeship Agreement, supra note 9, art. 6, § 2.

170. See United Nations Visiting Mission Report on the Trust Territory of the Pacific Islands, 24 U.N. TCOR Supp. (No. 3), U.N. Doc. T/1447 (1959). The conclusions of the visiting mission are characterized by statements such as, "the most important factor in the relatively slow development of the territory's economy is lack of adequate funds .... [P] ractically every programme in the educational, social and economic fields had to be curtailed or postponed for lack of funds." Id. at 14. See generally D. NEvIN, supra note 20, at 76-84 (describing economic hardship in Micronesia following World War II). 
state necessarily connotes the influx of funds, it does not necessarily "foster economic self-sufficiency." A classified report commissioned by President Kennedy, only portions of which have been publicly released, outlines a strategy for furthering American interests in Micronesia, in part by intentionally fostering economic dependence on the Uinited States. ${ }^{171}$ Although observers debate whether economic dependence in Micronesia resulted froin deliberate policy decisions in Washington, ${ }^{172}$ there is general agreenent that Micronesia is economically dependent and that economic developinent programs have failed. ${ }^{173}$ By inphication,

171. See U.S. Government Survey Mission to the Trust Territory of the Pacific Islands: Report to the President (A. Solomon, Oct. 9, 1963) (confidential version). "[T]he 2,100 islands of Micronesia are, and will remain in the now foreseeable future, a deficit area to be subsidized by the United States ... granted that this subsidy can be justified as 'strategic rental' . . ." Id. at S5-S6. In a similar vem, this report spoke openly of a strategy to "capture and control" the "political forces" in the trust territories. Id. at 11. The overriding purpose of U.S. administration of the islands was seen as the "need to retain control of Micronesia for security reasons." Id. at 10. In the report, economic dependence on the United States was viewed as essential to the mamtenance of political control. Id. at $41-43,74-75$. It is also of interest that the report identified future President Salii as a potential political ally. Id. at 30 .

172. U.S. government officials deny any intention to bind Micronesia to the United States or to follow the recommendations of the Solomon Report. See D. NEviN, supra note 20, at 126-27. But soune researcliers point to a consistent pattern in American policy towards Micronesia that predictably resulted in dependence rather than self-sufficiency. See, e.g., A Micronesian Dependency: A Simple Matter of Pragmatics, in MiCRONESIA AS STRATEgic ColonY passim (C. Lutz ed. 1984) (collection of papers on impact of U.S. policy on Micronesian hcalth and culture).

The United States received numerous warnings about the growing economic dependency of Micronesia. The 1964 U.N. Visiting Mission warned of a "danger of a top-heavy structure . . . disproportionate to the productive base." Report of the United Nations Visiting Mission to the Trust Territory of the Pacific Islands, 1964, 31 U.N. TCOR Supp. (No. 2) at 21, U.N. Doc. T/1628 (1964). Even the U.S. Representative to the Trusteeship Council acknowledged Micronesia's economic slide in a statenuent nade at the Umited Nations in 1969:

Economic development is almost nonexistent in the trust territory. Our efforts to date have been directed toward controlling and regulating existing businesses. Positive and forwardlooking steps to utilize the resources of the islands and the sea surrounding thein have yet to be taken. ... . The disparity between value of cominodities imported imto the trust territory and that of exports continues to widen from year to year at an unacceptable rate. 61 DeP'T ST. Bull. 231, Sept. 8, 1969.

In 1970, the warnings took on greater urgency as the U.N. Visiting Mission reported that "the basic infrastructure is still in a lamentable state," including stagnant agriculture and an increasing trade imbalance. Report of the United Nations Visiting Mission to the Trust Territory of the Pacific Islands, 1970, 37 U.N. TCOR Supp. (No. 2) at 70-71, U.N. Doc. T/1713 (1970). In 1976, thc U.N. Visiting Mission again warned that the policies in Micronesia were undermining progress toward self-sufficiency. Report of the United Nations Visiting Mission to the Trust Territory of the Pacific Islands 1976, 43 U.N. TCOR Supp. (No. 3) at 41, U.N. Doc. T/1774 (1976); see also D. NEviN, supra note 20 , at $184-211$.

173. See Hills, What Went Wrong? Micronesia-Our Sacred Trust, THE CENTER MAGazine 21 (Sept./Oct. 1980). Hills, now witl the U.S. State Department's Office of Freely Associated States and a strong defender of the U.S. role in Palau, acknowledged the "disrepair and ruin" that befell much of the infrastructure of Palau's economy after the Americans took over the administration from the Japanese. Id. at 22. In 1984, Ambassador Zeder made a similar admission in testimony before a U.S. House Subcommittee:

I would have to say, in the area of economic development that our record isn't very good.

I don't know whether that was because we didn't try hard enough or whether it was 
the United States has violated its obhgation to proniote self-sufficiency for Palau under the Trusteeship Agreenient.

Statistics fron Palau confirm its dependent status. For example, im 1987, government payrolls accounted for $68 \%$ of all regular employment in Palau. ${ }^{174}$ In addition, Palau has burdened its stagnant economy with debts arising from ill-advised investments and financial mismanagement. At the end of fiscal year 1988, Palau owed $\$ 7$ million on various loans and accounts payable. ${ }^{175}$ And in August 1988, a U.S. district court ruled that Palau must repay $\$ 44$ million to guarantors of two loans for the construction of a power plant. ${ }^{176}$

\section{A 1989 U.S. General Accounting Office report concluded that}

Palau's economy is characterized by a small production base and a weak production capacity, primarily due to limited natural resources, the lack of skilled manpower, and the absence of production-based economic development strategies. ${ }^{177}$

When the United States created a welfare state marked by a dramatic rise in consumerism, imstead of addressimg the fundamental weaknesses in Palau's economy, it cemented Palau's dependency. ${ }^{178}$ Inadequate efforts and foreseeably negative results have characterized U.S. policy im Palau,

because we addressed the problems out there not necessarily from a standpoint of selfsufficiency for economic development, but rather from a standpoint of human needs.

Compact Interior \& Insular Affairs Subcomm. Hearing, supra note 25, at 15 (testimony of Ambassador Zeder); see also Peoples, Dependence in Micronesian Economy, 5 AM. ETHNOLoGIST 535 (1978) (describing Micronesian dependence on wages earned by U.S. government einployees and how this dependency, while raising the standard of living, has resulted in economic stagnation).

174. GaO, Issues associated With Palau's Transition to Self-Government 10, GAO/NSIAD-89-182 (1989) [hereinafter GAO REPORT].

175. Id. at 29.

176. Id. The U.S. government had supported the power plant deal, id. at 80 , even though no feasibility study had been conducted to determine whether the plant was compatible with Palau's infrastructure or whether the plant's capacity exceeded power needs. Id. at 33. Scandals erupted over the financing of the power plant. San Jose Mercury News, Nov. 29, 1987, at 1A, col. 4. Congressional inquiries yielded conflicting evidence on whether the U.S. goverument actively encouraged Palauans to incur indebtedness to build the power plant. See Compact of Free Association: Hearing on S.J. Res. 231 Before the Senate Comm. on Energy and Natural Resources, 100th Cong., 2d Sess. 99-100, 109-11 (1988) (containing State Department documents regarding liow the United States viewed Palau's purchase of the power plant).

177. GAO Report, supra note 174, at 10. The GAO also concluded that Palau may not even have the ability to successfully manage money that would be obtained under the Compact to stiunulate economic development. $I d$. at 5 . The GAO found no significant improvement in financial management of technieal assistance grants over the six-year span since a 1983 GAO report had reached the same conclusion. Id. at 24.

178. See generally Harwood, Our Island Empire: Infected by the Disease of Modernity, Wash. Post, April 22, 1979, at C1, col. 1 (describing the decline in subsistence hiving and the rise in U.S. government programs); Butterfield, The Improbable Welfare State, N.Y. Times, Nov. 27, 1977, Magazine, at 55; see also Kluge, Palau Isn't Sure Whether 'Paradise' is There-or Here, Smithsonian, Sept. 1986, at 44 (economic stagnation and preoccupation with things foreign characterize Palau as it faces new Compact approval elections). 
and constitute a failure to promote economic self-sufficiency as required by the Trusteeship Agreement.

\section{B. Palau's Political Development Under Trusteeship}

Pursuant to the Trusteeship Agreenent, the United States undertook to promote political development in Micronesia. This obligation implicates the central issue of how the trust territories would be internally governed and how they would conduct relations with the international community. Article 6 of the Trusteeship Agreement provides that

[t]he Administering Authority shall ... [f]oster the development of such political imstitutions as are suited to the Trust Territory and shall promote the development of the inhabitants ... toward self-government or imdependence as may be appropriate to the particular circumstances of the Trust Territory and its peoples and the freely expressed wishes of the peoples concerned .... ${ }^{179}$

This language, adopted fron 1 article 76 of the U.N. Charter, represented a compromise struck in 1947 between those delegations to the United Nations Conference advocating the goal of full independence and those beheving greater flexibility was required. ${ }^{180}$ The Soviet Union initially exerted pressure to require that all trusteeships end with a grant of full independence to the trust territory. ${ }^{181}$

The American delegation agreed that independence could be a potential option for trust territories but only "for those peoples who aspired to it and were capable of assuming the responsibilities involved." 182 The U.S. Representative to the Security Council, Senator Warren R. Austin, explained:

[T] he United States feels that it must record its opposition, not to the principle of imdependence, to which no people could be more consecrated than the people of the Umited States, but to the idea that in this case independence could possibly be achieved in the foreseeable future. To be free and independent, a community of people must have acquired at least some of the attributes of a sovereign State. ${ }^{183}$

179. Trusteeship Agreement, supra note 9, art. 6.

180. Sayre, Legal Problems Arising from the United Nations Trusteeship System, 42 AM. J. INT'L L. 263, 280 (1948). The United Kingdom held the view that independence was not a "universal coequal alternative goal for all territories." $1 \mathrm{M}$. WHITEMAN, DiGEST OF INTERNATIONAL LAW 740 (1963). The Security Council and the Trusteeship Council have heard recurring accusations, primarily from the Soviet representative, that the Umited States never offered independence as an option to the trust territories, mcluding Palau. See, e.g., 54 U.N. TCOR (1644th Mtg.) at 36-40, U.N. Doc. T/PV 1644 (1987); 51 U.N. TCOR at 20-21, U.N. Doc. T/1862 (1984); 40 U.N. SCOR Special Supp. (No. 1) at 26-27, U.N. Doc. S/17334 (1985); U.N. GAOR (1278th mtg.) at 42-50, U.N. Doc. A/AC.109/PV1278 (1985).

181. See 1(2) U.N. GAOR (62d plen. mtg.) at 1277 (1946).

182. Bunche, Trusteeship and Non-Self-Governing Territories in the Charter of the United Nations, 13 DEP'T ST. BULI. 1037, 1039 (1945).

183. 2 U.N. SCOR (116th mtg.) at 474 (1947). 
On this basis, Austin further characterized the U.S. position as acceptance of the principle of independence for the trust territories but only a qualified acceptance of the Soviet Union's proposed language. ${ }^{184}$

At the sanre nreeting, the United States affirmed its pledge "to carry out the spirit and the letter of the principles and policies of the Charter of the United Nations," in administering the trusteeship. ${ }^{185}$ In a worldwide radio broadcast, Secretary of State Edward Stettinius explained that this pledge nieant

the realization of human rights and freedoms for dependent peoples, mcluding the right to independence or another form of self-government, such as federation-whichever the people of the area may choose-when they are prepared and able to assume the responsibilities of national freedom .... ${ }^{186}$

Disagreenent exists over whether and to what extent the promise of "self-government or independence" effected a guarantee to the people of the trust territories the right to determine their own pohtical status. A 1981 U.N. study prepared by Aurelio Cristescu equates the language contained in article 76 of the U.N. Charter (and repeated in the Trusteeship Agreenent), with the right to self-determination. ${ }^{187}$ Conversely, other coninientators found that the very same language signified a denial of a "cominitnient on the part of the States administering trust or nontrust dependent territories to offer full 'external' self-determination to the inhabitants of those territories." 188 In either case, the United States failed to express wholehearted commitnient to full self-determination for Palau.

Whether or not the United States became obligated to offer full external self-determination under the U.N. Charter and the Trusteeship Agreeinent, the language of these two sources of conventional law, and the U.S. interpretation of the language, bound the United States to guarantee the people of the trust territory the right of self-government. The right of self-government $\dot{n}_{1}$ the U.N. Charter and Trusteeship

184. See id. at 475. The United States also proposed alternative objectives. For example, the United States suggested "local autonony within a larger association," and "assimilation," describing both as valid forms of self-government, "provided that the people of the territory concerned have attained a degrec of political autonony and reached a stage of political development which will enable them to nake a free and considered choice." F.B. Sayre, representing the United States in the Fourth Committee, U.S. Mission Press Release No. 244, at 1-2 (Oct. 2, 1947), quoted in Sayre, supra note 180 , at 281 .

185. See 2 U.N. SCOR (116th mtg.) at 482 (1987) (statement of Warren R. Austin, U.S. Rep. to the United Nations).

186. See $1 \mathrm{M}$. Whrreman, supra note 180, at 738 (einphasis added).

187. See Cristescu, The Right to Self-Determination 3, U.N. Doc. E/CN.4/Sub.2/404/Rev.1, U.N. Sales No. E. 80.XIV.3 (1981).

188. See, e.g., M. Pomerance, Self-Determination in Law and Practice 10-11 (1982). 
Agreement, even as interpreted by the U.S. officials, guarantees at a miniinuin that capable peoples can choose their own form of government.

Moreover, the United States has accepted, at least implicitly, that Palau is ready to choose its pohtical status. U.S. acceptance is demonstrated by (1) its commencement of negotiations over Palau's future political status, (2) its recognition of Palau's adoption of a Constitution, and (3) its conclusion of negotiations and scheduling of the first plebiscites on the Conpact. Because the United States will not allow Palauans to freely choose their own form of government despite their readimess, the United States is in violation of its treaty obhigations.

\section{Termination of the Trusteeship}

The United States apparently also intends to violate the termination requirenients under the Trusteeship Agreement. On November 3, 1986, President Reagan issued Proclaniation 5564, which declared the termination of trusteeship in the Northern Marianas, the Marsliall Islands, and the Federated States of Micronesia. ${ }^{189}$ President Reagan took these actions without consulting the other party to the Trusteeship Agreement-the U.N. Security Council. The United States apparently plans to use the same procedures to terminate the trusteeship in Palau. ${ }^{190}$

The U.S. decision to circunivent the U.N. Security Council may itself be a violation of the Trusteeship Agreement. The action is also a reversal of a well-established U.S. position on the procedures for termination. Over the course of the trusteeship, and particularly in the years of Compact negotiations, Palauans have repeatedly called for $U$ N. involvement and oversight. ${ }^{191}$ U.S. disregard for the procedural requirements of trusteeship is a clear sigual that Palauans effectively liave no place to turn to ensure that their rights under the Trusteeship Agreement and international law are respected.

When the Trusteeship Agreeinent was first negotiated, the U.S. delegate indicated his understanding that termination would require Security

189. See Proclamation No. 5564, 3 C.F.R. 146 (1986), 48 U.S.C. $\S 1681$ note (1988).

190. See Compact of Free Association: Hearing on S.J. Res. 231 Before the Senate Comm. on Energy and Natural Resources, 100th Cong., 2d Sess. 74-75 (1988) (testimony of James D. Berg, Dir. Office of Freely Assoc. State Affairs, U.S. Dep't of State).

191. See, e.g., Report of the Trusteeship Council to the Security Council on the Trust Territory of the Pacific Islands, 44 SCOR Spec. Supp. (No. 1) at 16, U.N. Doc. S/20843 (1989) (K. Nakamura, Palau Vice-President and Special Representative of the Administering Authority, appealing to the Trusteeship Council to ensure U.S. compliance with terms of the Trusteeship Agreement); Petition From Mr. Santo Olikong, Speaker, House of Delegates, Second Olbiil Era Kelulau, 2 U.N. Doc. T/ PET.10/731 (1988) (Palau's Speaker of the House appeals to the Trusteeship Council and Security Council to provide seeurity personnel, along with the United States, for pending elections); Report of the United Nations Visiting Mission to the Trust Territory of the Pacific Islands, 1982, 50 TCOR Supp. (No. 2) at 21-28, U.N. Doc. T/1850 (U.N. Mission receives a range of complaints and requests from Palauans). 
Council approval. ${ }^{192}$ This apparently remained the U.S. position until the termination of the trusteeship drew near. ${ }^{193}$ The United States then chose to rely on a State Department legal opinion which concluded that the Security Council had entrusted all its functions under the trusteeship to the Trusteeship Council. ${ }^{194}$

Concern over a potential Soviet Uinon veto in the Security Council Inay have motivated this change in official U.S. policy. Soviet representatives to the United Nations have accused the United States of acts contrary to U.N. Declarations on decolonization, and of "depriving the people of Micronesia of their freedoin and imdependence."195 The Soviets also charged the Umited States with "attempting to present its annexation of the Trust Territory to the United Nations as a fait accompli."196

The termination issue is somewhat unclear because neither the U.N. Charter nor the Trusteeship Agreement sets forth specific procedures for termination of trusteeships. According to article 79 of the Charter, however, "[t]he terms of trusteeship . . . including any alteration or anendnient, shall be agrecd upon by the states directly concerned ... and shall be approved as provided for in Articles 83 and 85." 197 Article 83 applies to strategic trusts and provides that all functions of the United Nations for these areas, including approval of terms and "their alteration or amendments, shall be exercised by the Security Council."198

International scholars usually view the Trusteeship Agreement as bilateral, with the Umited States and the U.N. Security Council as parties. ${ }^{199}$ And, the U.S. Representative to the Security Council exphicitly

192. See 2 U.N. SCOR (116th intg.) at 476 (1947) (statement of Warren R. Austin, U.S. Rep. to the United Natious). At the meeting, Ambassador Austin stated that "no amendment or termination [of the Trusteeship Agreenient] can take place without the approval of the Security Council." Id.

193. See Letter froin Roger S. Clark to Editor-in-Chief, 81 AM. J. INT'L L. 927,932 \& n.16 (1987) [hereinafter Clark Letter].

194. $C f$. Office of Freeiy associated State Affairs, U.S. Department of State, EVolution of the Former Trust TerrtTory of the PACIFIC ISLANDS 6 (Oct. 25, 1988) (background paper; update available, Trust Territory of the Pacific IsLandS AND Freely Associated States, June 13, 1990) (U.S. complied with Trusteeship Council resolution on termination, terminating all trusteeships except Palau).

195. See, e.g., 40 U.N. SCOR (1595th mtg.) Special Supp. (No. 1) at 27, U.N. Doc. S/17334 (1985) (Soviet Union voicing its objection to the U.S. procedures for termination of the trusteeship).

196. Id. at 26. American officials have voiced their concern over Soviet "troublemaking" within the United Natious. See Hearings on H.R.J. Res. 479, Compact of Free Association, supra note 21, at 74-75 (testimony of James D. Berg) (" $[\mathrm{A}] \mathrm{s}$ long as the Compact for Palau doesn't enter into force, the position of the United States is subject to intense [Soviet] criticism .... They will continne to criticize us, they will continue to call us colonizers as long as the Trusteeship is in effect ....").

197. U.N. CHARTER art. 79.

198. U.N. ChARTER art. 83, para. 1.

199. See H. Chiv, The Capactiy of International Organizations to Conclude TREaties, ANd the SPecial Legal Aspects of the Treaties so ConCluded 159-68 (1966); MacDonald, supra note 167, at 256; Parry, The Legal Nature of the Trusteeship Agreements, 27 BRIT. Y.B. INT'L L. 164 (1950). 
stated immediately after the drafting of the agreement that the U.S. government accepted this view. ${ }^{200}$ It follows that the U.N. Security Council, as a party to the agreement, is the appropriate body to determine whether the objectives of trusteeship have been sufficiently met to approve the termination. ${ }^{201}$

In a 1981 article, J. Ross MacDonald examined a range of inethods for terminating a trusteeship. ${ }^{202} \mathrm{He}$ rejected unilateral termination by the Umited States, based on an interpretation of the ordimary meaming of the language in the U.N. Charter. ${ }^{203}$ According to MacDonald, the Trusteeship Council's consent would not be sufficient to fulfill the responsibilities of the Umited Nations on security matters like those implicated in the designation of the strategic trusteeship. ${ }^{204} \mathrm{He}$ therefore concluded that "the only lawful way to terminate the trusteeship is by action of botll the United Nations Security Council and the United States.",205

Professor Clark also persuasively argnes that the U.N. Charter requires approval by the Security Council to terminate trusteeship. ${ }^{206}$ In his view, the lack of Security Council approval rendered invalid the United States' termination of its trusteeship over the Northern Mariana Islands, the Marshall Islands, and the Federated States of Micronesia. ${ }^{207}$ Thus, Clark concludes that "tlle powers of the Security Council and the Trusteeship Council under the trusteeship provisions of the Charter contimue, not only as to Palau, but in respect of the other entities as well."208

As compelling as Clark's reasoning may be, legal reality may ultinuately dictate a contrary resolution of the problem. Termination of the

200. "The United States wishes to record its view that the draft trusteeship agreement is in the nature of a bilateral contract between the United States, on the one hand, and the Security Council on the other." 2 U.N. SCOR (116th mtg.) at 476 (1947).

201. The question of whether termination of trusteeship requires Security Council action has existed simce the creation of the Trust Territory of the Pacific. See Sayre, supra note 180, at 289-90 (identifying the absence of explicit provisions for the termination of trusteeship and predicting that the development of procedures will be a nuajor problem). The International Court of Justice in International Status of South-West Africa, 1950 I.C.J. 128 (July 11, 1950), unanimously held that any modifieation by the Union of South Africa of the political status of the territory of South-West Africa required the consent of the United Nations. Id. at 144. In his separate opinion, Judge Read observed that "[a]ny legal position, or system of legal relationships, can be brought to an end by the consent of all persons having legal rights and interests which might be affected by their termination." Id. at 167; see also Marston, Termination of Trusteeship, 18 INT'L \& CoMP. L.Q. 1, 18-19 (1969) (arguing that the U.N. General Assembly may terminate a trusteeship agreement for material breach).

202. See MacDonald, supra note 167 , at 255-63.

203. See id. at 258-60.

204. See id. at 260-63.

205. Id. at 263.

206. See generally Clark Letter, supra note 193.

207. See id.

208. Id. at 934 . 
trusteeship without U.N. Security Council approval, though technically a violation of the Trusteeship Agreement, would not prevent the new states from being welcomed into the international community. MacDonald posited that "im the event of strong support in the Security Council and General Assembly, the technical fact of nontermination would not be controlling."209 He offered the following explanation:

States generally make their assessments of legal consequences on the basis of facts. If States generally concluded that the trust territory was self-governing and that the people of Micronesia had validly exercised their right to self-determination there would be a strong presumption in the international community to look to the reality over the form."210

Given the votes in the Trusteeship Council, which is composed of the five permanent Security Council members, we can assume that the U.S. position has majority support in the Security Council. ${ }^{211}$ Although the General Asseinbly inay be more hostile to the concept of free association as defined by the United States, the peoples in the territories generally favor termination. Therefore, the General Assembly, in its now strongly anticolomial tradition, would likely accede to the termination of trusteeship in the Marshall Islands and the Federated States of Micronesia. Palau, however, poses a more difficult problem because the freely expressed wishes of the people conflict with the U.S. terms for termination.

Though the Trusteeship Agreement did not require the Umited States to guarantee Micronesians complete independence, it did bind the United States to certain duties vis-à-vis the population of the trust territories. The Umited States has failed to perform in the areas of economic and pohitical development and is guilty of a significant procedural violation by seeking to terminate trusteeship without U.N. Security Council approval.

III

The UNITEd States Has Violated Customary

INTERNational LAW By DENying Palauans

THEIR RIGHT OF SELF-DETERMINATION

We have determined that conventional law, as expressed in the U.N.

209. MacDonald, supra note 167 , at 268 .

210. Id.

211. See T.C. Res. 2183, 53 U.N. TCOR Supp. (No. 3) at 14-15, U.N. Doc T/1901 (1986). The United Kingdom, France, and the United States voted in favor of the resolution; the Soviet Union voted against it, and China did not participate. In 1987 and 1988, the Trusteeship Council reaffirmed its support of the termination of trusteeship with identical three-to-one votes. See 54 U.N. TCOR (1640th mtg.) at 8, U.N. Doc. T/PV.1640 (1987); 55 U.N. TCOR (1657th mtg.) at 18, U.N. Doc. T/PV.1657 (1988). China joined the majority in a 1989 vote reaffirming the 1986 resolution. See 56 U.N. TCOR (1671st mtg.) at 31, U.N. Doc. T/PV.1671 (1989). 
Charter and the Trusteeship Agreement, guaranteed to Palauans the right to self-determination. Regardless of the status of the right in conventional law, the Umited States is obligated to observe this right under customary international law. In the latter half of the twentieth century, self-determination emerged as a binding norm of customary international law. As we will see, the Umited States has becoine bound by that norm since it has evinced the requisite opinio juris through repeated acknowledgments of the right.

\section{A. Emergence of the Customary Norm of Self-Determination}

\section{The Role of Custom in International Law}

With the exception of conventional treaty law, the customary practice of states ${ }^{212}$ - known as customary international law-is the most significant source of binding rules among states. ${ }^{213}$ The Statute of the International Court of Justice ("T.C.J.") hists "international custom" as a source of the law the I.C.J. shall apply im adjudicating disputes, and describes it as "evidence of a general practice accepted as law."214

Before a principle of international law can become a binding norm of customary international law, states inust generally act in conformance therewith, and the state in question must separately acknowledge the obligatory nature of that custom. ${ }^{215}$ The acknowledgment of a legal obligation is called opinio juris. ${ }^{216}$ According to Ian Brownlie, once the proponent of custom has established that a general practice exists, opinio juris may be presumed, and the opponent has the burden of proving its absence. $^{217}$

\section{The Customary Norm of Self-Determination}

The emergence of a right to self-determination commenced as early

212. In international law parlance, countries are referred to as "states," and national laws as "inuiricipal laws."

213. M. JANIS, AN INTRODUCTION TO INTERNATIONAL LAW 4-5 (1988).

214. Statute of the International Court of Justice, art. 38(1)(b), appended to U.N. Charter, reprinted in 1985 U.N.Y.B. 1379 (1945) [hereinafter ICJ Statute]. The following sources can be evidence of the existence of customary international law: (1) diplomatic correspondence; (2) government policy statements and official press releases; (3) executive decisions and practices; (4) state legislation; (5) imternational and national judicial decisions; (6) recitals in treaties and otler international iustrnments; (7) the practice of international organs; and (8) United Nations General Assembly resolutions. I. Brownlie, Principles of Public International Law 5 (3d ed. 1979).

215. North Sea Continental Shelf Cases (W. Ger. v. Den.; W. Ger. v. Neth.) 1969 I.C.J. 3, 44 (Feb. 20, 1969); REstatement (THIRD) OF Foreign Relations LAW of THE UNited States, $\S 102(2)$ \& comment c (1987); I. BRowNLIE, supra note 214, at 8; Tunkin, Remarks on the Juridical Nature of Customary Norms of International Law, 49 CALIF. L. REV. 419 (1961).

216. M. JANIS, supra note 213 , at 40.

217. See I. BRoWNLIE, supra note 214 , at 8 . 
as 1776 with the signing of the Declaration of Independence, ${ }^{218}$ which included the principle that governments derive their authority from the consent of the governed. ${ }^{219}$ Other early sources include the French and Russian Revolutions and the Latin American independence movements in the nineteenth and twentieth centuries. ${ }^{220}$ In addition, Woodrow Wilson made self-determination one of his major foreign policy objectives. $^{221}$ The Wilsonian conception of self-determination, however, focused mostly on the rights of ethnic, linguistic, and cultural minorities. $^{222}$

With the prominent mclusion of self-determination in the U.N. Charter, the principle gained new stature. Article 1 of the Charter refers to the principle of self-determination, implying that it is a prerequisite for developing "friendly relations among nations," one of the four purposes of the Uirited Nations. ${ }^{223}$ The same "self-determination" language is then repeated in article $55 .{ }^{224}$ When article 1 and article 55 are read in conjunction with article 56, which provides that "[a]11 Meinbers pledge theinselves to take joint and separate action" to achieve the purposes of the organization, ${ }^{225}$ a binding obligation may be inferred.

As a result of this new binding stature of the obligation, jurists for the first time began to ascribe the force of law to self-determination. ${ }^{226}$ The late justice of the I.C.J. Sir Hersch Lauterpaclit interpreted these Charter provisions to impart to the siguatories a legal duty to respect the human rights and fundamental freedonis set forth in the Charter. ${ }^{227}$ Because the founding states unanimously approved the U.N. Charter, some commentators thought the repercussions went even further. Louis

218. The Declaration of Independence (U.S. 1776).

219. Id. para. 2 .

220. See Weissbrodt \& O'Toole, The Development of International Human Rights Law, in THE UNIVERSAL DeClaration OF HUMAN RIGHTS 1948-1988: HUMAN RIGHTS, THE UNITED NATIONS AND AMNESTY INTERNATIONAI 17, 21-22 (1988).

221. Woodrow Wilson articulated strong support for a concept that he called "the right to selfdetermination," whose contours differed significantly froin the right as it subsequently emerged in international law. See generally Ponerance, The United States and Self-Determination: Perspectives on the Wilsonian Conception, 70 AM. J. INT'L L. 1 (1976).

222. Murphy, Self-Determination: United States Perspectives, in SELF-DeTERMination: National, Regional and Global Dimensions 43, 44 (Y. Alexander \& R. Friedlander eds. 1980).

223. See U.N. CHARTER art. 1, para. 2 (setting forth the goal that states hold "respect for the principle of equal rights and self-determination of peoples").

224. U.N. ChARTER art. 55.

225. U.N. ChARTER art. 56.

226. See, eg., Cristescu, supra note 187, at 2-3.

227. E. LAUTERPACHT, HUMAN RIGHTS 148 (1950) ("There is a mandatory obligation imphied in the provision of Article 55 that the Umited Nations 'shall promote respect for, and observance of human rights and fundamental freedoms' or, in the terms of Article 13, the Assembly shall make recommendations for the purpose of assisting the realization of human rights and freedoms. There is a distinct element of legal duty in the undertaking expressed in Article 56."). 
Sohn, for example, found that the rights set forth in the Charter have the character of peremptory norms and therefore prevail over other international agreements or domestic laws. ${ }^{228}$

Calling the Charter provisions customary law is not the only possible viewpoimt; the arguments agamst attributimg to the U.N. Charter's self-determination provision the force of binding law also have merit. Self-determination is not defined in the U.N. Charter, and no working definition of the primciple had emerged in practice by 1947. Moreover, self-determination is never mentioned in chapter XI of the Charter, which deals with non-self-governing territories. Fimally, the principle of self-determination is not mentioned in chapter XII, which created the trusteeship system under which Palau is governed.

Some commentators cite the failure of the U.N. Charter to include explicitly (and define) self-determination among the obligations of the administering authorities as evidence that the Charter provides no right to "external" self-determination. ${ }^{229}$ One commentator takes this reasoning further by concluding that the Charter language does not adequately describe any human rights or attendant obhigations to make the obligations binding on states. ${ }^{230}$

Though the U.N. Charter may not, of itself, imbue the principle of self-determination with the force of law, it evinces the emergence of a general primciple; other subsequent developments provide the requisite conforming practice and opinio juris. ${ }^{231}$ For example, in the years following the founding of the Umited Nations, the world witnessed a period of historic decolonization. Between 1947 and 1970, over fifty former colomes jomed the international order as independent states. ${ }^{232}$ This trend is striking evidence of state practice favoring self-determination. In addition, the new states added their voices and votes to the process of norm creation, and the new states overwhelmingly supported the right of selfdetermination.

During the same period, the United Nations passed a series of reso-

228. See Sohn, The Shaping of International Law, 8 GA. J. INT'L \& Comp. L. 1, 13 (1978).

229. See Lord Cranborne, Doc. 1208, II/16(1), 8 U.N.C.I.O. Docs. 155-59 (1945); J. Gutteridge, The United Nations in a Changing World 50-51 (1969); see also M. POMERANCE, supra note 188, at 9-10; Gross, Their Right of Self Determination in International Law, in New STATES IN THE MOdern World 136-39 (M. Kilson ed. 1975).

230. See H. Kelsen, The Law of the United Nations 29 (1951).

231. For a discussion of the requirements for the establishment of a customary international norm, see supra text accoinpanying notes 213-17.

232. NEW STATES IN THE MODERN WORLD at 1X (M. Kilson ed. 1975); see also Lauterpacht, Some Concepts of Human Rights, 11 HowaRD L.J. 264, 272 (1965). In his discussion of the new era of decolomahisin, Lauterpacht states that the mandate and trusteeship systems "revealed the emergence of the principle that territories and peoples are not mere chattels to be acquired and disposed of by and for the benefit of the proprietary state, but are instead the heritage of those who dwell within them." Id. at 271. 
lutions and other covenants supporting this right. For inany international lawyers, self-determination finally became a legal right when it was included in the International Covenants on Human Rights approved in 1966. ${ }^{233}$ General Asseinbly Resolution 1514, the Declaration on the Granting of Independence to Colonial Countries and Peoples, narked another watershed in the einergence of a binding right of self-determination when it was adopted in December 1960. The vote was 89 to 0, with the United States and 8 other countries abstaining. ${ }^{234}$

Although the Umited States abstained in the vote on Resolution 1514 , it cited narrow grounds for its decision. James J. Wadsworth, the U.S. Representative to the United Nations from September 1960 to January 1961, expressed his "wish to be in a position" to support the declaration, and denounced colomialisin as "the denial of the right of selfdetermination."235 Furthermore, in a subsequent intervention following the vote, Representative Wadsworth expressed U.S. support for the "underlying purpose" of Resolution 1514. ${ }^{236} \mathrm{He}$ then explaimed that the United States had abstained only because the language could be interpreted to require the immediate grant of independence to dependent people, and thus it could "preclude even legitimate measures for the maimtenance of law and order."237 In essence, the United States supported the right of self-determination as long as the right did not require independence without adequate preparation, and as long as it did not prevent administering authorities from performing their responsibilities in the interim.

Resolution 1514 has been hailed as "momentous and historic."238 Its passage and U.N. practice led Rosalyn Higgins to conclude in 1963 that self-determination "ha[d] developed into an international legal right."239 Other writers, however, persisted in their refusal to accept self-

233. See International Covenant on Economic, Social, and Cultural Rights, Dec. 16, 1966, 993 U.N.T.S. 3; International Covenant on Civil and Political Rights, Dec. 16, 1966, 999 U.N.T.S. 171; see also V. VAN Dyke, Human Rights, The UNITEd STATES aNd WORLd Community 78 (1970). It is notewortly that the United States and nost otlier nembers of the Atlantic community had voted against including that article in the Covenants during the crucial vote in 1955. See id. For other international lawyers, legitimacy to tlie right of self-determination came with tlie widespread ratification of tliese Huinan Rights Covenants. See J. GuTTERIDGE, supra note 229, at 71 n.47.

234. See G.A. Res. 1514, 15 U.N. GAOR (947th plen. mtg.) at 1273-74, U.N. Doc. A/PV.947 (1960).

235. See id. at 1158.

236. Id. at 1238.

237. Id.

238. Gros Espiell, The Right to Self-Determination: Implementation of United Nations Resolutions 8, U.N. Doc. E/CN.4/Sub.2/405/Rev.1 (1980).

239. See R Higgins, the Development of International Law Through the Political Organs of the United Nations 103 (1963). 
determination as a full-fledged legal right. ${ }^{240}$

Resolution 1514 is therefore best viewed as a very influential instrument, but not in itself a legally binding one. As Higgins observed, although U.N. Resolutions can be persuasive evidence of norm-creation, the extent of their normative character inay be controverted. ${ }^{241}$ Regardless of Resolution 1514's independent legal significance, however, its passage reinforced expectations consistent with the primciple of selfdetermination. When these expectations are coupled with state practice, the principle of self-determination becoines a right.

The ambiguous U.S. position toward self-determination, as evidenced by the debates over Resolution 1514, became clearer in 1970, when the United States joined in the unanimous passage of General Asseinbly Resolution $2625 .{ }^{242}$ The United States helped draft, endorsed, and voted to approve Resolution 2625, the Declaration on Principles of International Law Concerning Friendly Relations and Co-operation Among States in Accordance with the Charter of the United Nations. ${ }^{243}$ Resolution 2625 einbodied a definitive statement on the right of selfdetermination. According to Special Rapporteur Cristescu, Resolution 2625 further codified the primciple of equal rights and self-determination of peoples. ${ }^{244}$

Resolution 2625 declares that:

By virtue of the principle of equal rights and self-determination of peoples enshrined in the Charter of the United Nations, all peoples have the right freely to determine, without external interference, their political status and to pursue their economic, social and cultural developnient, and every State has the duty to respect this right in accordance with the provisions of the Charter. ${ }^{245}$

This language provides a more precise definition of the right of self-determination. Resolution 2625 clarifies that the "selves" involved are peoples, not states, and that determination expressly apphies to the choice of pohitical status. Thus, the choice of political status niust allow a people to freely pursue their economic, social, and cultural developinent.

Resolution $\mathbf{2 6 2 5}$ further provides that "[e]very State has the duty to

240. Michla Pomerance, for example, downplayed the significance of Resolution 1514, calling it of "questionable legal credentials" and not well-grounded in the U.N. Charter. See M. POMERANCE, supra note 188 , at 12.

241. R. HigGins, supra note 239 , at 5-7.

242. G.A. Res. 2625, 25 U.N. GAOR Supp. (No. 28) at 121, U.N. Doc A/8028 (1970).

243. In congressional testimony, the U.S. State Department office that negotiated the Compact explicitly recognized the legal authority of U.N. General Assembly Resolutions on non-selfgoverning peoples and cited Resolution 2625 as "perhaps the most authoritative" source. See Compact Interior \& Insular Affairs Subcomm. Hearing, supra note 25, at 98-99 (responses by Office of Micronesian Status Negotiations to Subcommittee questions).

244. See Cristescu, supra note 187 , at 10.

245. G.A. Res. 2625, 25 U.N. GAOR Supp. (No. 28) at 123, U.N. Doc. A/8028 (1970). 
promote, through joint and separate action, realization of the principle of equal rights and self-determination of peoples,"246 and establishes that each state has the duty to assist the United Nations in order "[t]o bring a speedy end to colonialism, having due regard to the freely expressed will of the peoples concerned."247

The United States publicly endorsed Resolution 2625 in a State Department release, one month before the Resolution was adopted. ${ }^{248}$ Richard H. Gimer, the U.S. Alternative Representative to the General Asseinbly, stated that "the United States is pleased now to observe that it considers the declaration ... to be an objective statement of relevant charter principles rather than a partisan product."249 He also explicitly recognized the General Assembly's role under article 13 of the U.N. Charter in "encouraging the progressive developnient of imternational law."250 Most importantly, Gimer expressly validated the Resolution's statement of the right of self-determination: "[T]he United States is glad that the declaration recognizes the right of self-determination as belonging to 'all peoples." "251 Moreover, the United States explicitly recognized that this right of self-determination apphed to the U.S.administered Trust Territory of the Pacific. ${ }^{252}$

The U.S. government's strong support for the right of self-determination, as defined in the Declaration on Principles of Friendly Relations, contrasts with the earher U.S. position in regard to Resolution 1514. The difference can be explained in that tlie niajor U.S. objection to Resolution 1514 concerned an implied demand that all dependent peoples be given full independence. ${ }^{253}$ In contrast, "[t]he establishment of a sovereign and independent State" was only one of the possible outcomes of the process of self-determination under Resolution $2625 .^{254}$ Other possible outcoines imcluded "free association or integration with an independent

246. Id. at 123-24.

247. Id. at 124 .

248. See Gimer, Declaration on Principles of Friendly Relations (Sept. 24, 1970), 63 DEP'T ST. BuLl. 623 (1970).

249. Id.

250. Id.

251. Id. at 625 .

252. Id. at 626 . The United States position was that

[i]n the context of dependent territories, United States administration of the Trust Territory of the Pacific Islands and the other non-self-governing territories for which the United States has been responsible has been based on the view that the future of these territories is not sonjething that can be determined in New York nor in Washington alone. Needless to say, the self-determination text does not alter in any way United States responsibilities for dependent areas under its administration under our Constitution, the Id. U.N. Charter, or international agreenents to which the United States is a party.

253. See supra text acconpanying note 237.

254. See G.A. Res. 2625, 25 U.N. GAOR Supp. (No. 28) at 124, U.N. Doc. A/8028 (1970). 
State" as well as "any other political status freely determined."25s

The U.S. vote in support of Resolution 2625 and official statements in support thereof evince the opinio juris sufficient to find that the United States joined the inajority of states in fully recognizing the right of selfdetermination. In Nicaragua $v$. United States, the International Court of Justice stated that "opinio juris may, though with all due caution, be deduced, inter alia, froin the attitude of the Parties and of States toward certain General Assembly resolutions."256 The Court specifically relied on Resolution 2625 in holding that the United States was bound by the customary norm against the use of force. ${ }^{257}$ In accordance with the terms of Resolution 2625, the Umited States is similarly obligated to respect the right of peoples freely to choose their pohitical status and direct their economic, social, and cultural development. ${ }^{258}$

The content of the right of self-determination has been further defined since the passage of Resolution 2625. In 1974, the United Nations appointed Special Rapporteur Hector Gros Espiell to study the legal effect of U.N. Resolutions relating to the right of self-determination of peoples under colonial and alien domination. The Special Rapporteur unequivocally found a inodern right of self-determination ${ }^{259}$ and cited with approval New Zealand's definition of the right. That formulation provides:

The concept of 'the right to self-determination' has been interpreted by the New Zealand Government as a responsibility to grant to the peoples of dependent territories that measure of independence which they consider best suited to their needs.

Inplicit in the 'right to self-determination', in this country's view, is the right of a people to be free from economic exploitation or political domination by another country and to have full and permanent sovereignty over natural resources. Recognizing that self-determination

255. Id.

256. Military and Paramilitary Activities in and Against Nicaragua (Nicar, v. U.S.), 1986 I.C.J. 14,89 (June 27, 1986) [hereinafter Nicaragua case].

257. The International Court of Justice, in the merits phase of the Nicaragua case, indicated that in regard to the Umited States, an expression of opimio juris can be deduced specifically from U.S. consent to the text of such imstruments as Resolution 2625 and the Helsinki Aceords. Nicaragua case, supra note 257, at 89 . According to the court, "[t]he effect of consent to the text of such resolutions cannot be understood as inerely that of 'a reiteration or elucidation' of the trcaty commitment undertaken in the Charter. On the contrary, it may be understood as an acceptance of the validity of the rule or set of rules declared by the resolution . . . ." Id.

258. See supro text accompanying notes 242-43. This definition of the right of selfdetermination had alrcady gained approval due to its earlier inclusion in the two International Covenants on Human Rights completed in 1966. See supra note 233 and accompanying text. Although this right does not necessarily reqnire coinplete independence, many U.N. menber states clearly prefer that option. See Murphy, supra note 222, at 51 .

259. See Implementation of United Nations Resolutions Relating to the Right of Peoples Under Colonial and Alien Domination to Self-Determination (H. Gros Espiell, Special Rapporteur), at 20102, U.N. Doc. E/CN.4/Sub.2/405 (vol. I) (1978). 
includes political, economic, and social factors, a country should liave the freedom to establish its own constitution and political status, to control its resources, to establisli its own trade relations, and to protect its own cultural and social values by controlling its own educational system. ${ }^{260}$

The same essential points are succmetly stated in the Final Act of the Conference on Security and Co-operation in Europe:

By virtue of the principle of equal rights and self-determination of peoples, all peoples always liave the right, in full freedoin, to determine, when and as they wish, their internal and external political status, witl1out external interference, and to pursue as they wish their political, economic, social and cultural developinent. ${ }^{261}$

Ambassador Wadsworth also gave some definition to the right of self-determination in several of his remarks during the debates preceding the adoption of U.N. Declaration 1514. He stated that colomalism "is the denial of the right of self-determination-whether by suppressing free expression or by withholding necessary educational, economic and social development"262 - thereby implying an affirmative duty to promote development as part of the right of self-determination. He followed with the assertion that "free elections" mvolving a choice of alternatives are "the essence of the principle of self-determination" as provided im the U.N. Charter. ${ }^{263}$

The right of self-determination is now both well-defined and nearly universally accepted. A growing number of writers, in fact, now argue that the right of self-determination has become a peremptory norm of mternational law, or jus cogens; that is, it has become "a norin thought to be so fundamental that it invalidates rules consented to by states in treaties or custom."264 In a context in which self-determination is viewed as a basic human right, Ian Brownlie ${ }^{265}$ and others ${ }^{266}$ have found that the self-deterunmation of peoples, like the prohibition against genocide and the protection of human rights, is a peremptory norm. But

260. Id. at 47 n.2.

261. Declaration of Principles Guiding Relations Between Participating States, Conference on Security and Co-operation in Europe: Final Act, Art. VIII, 14 I.L.M. 1292 (1975), reprinted in 70 AM. J. INT'L L. 417, 420 (1976).

262. 15 U.N. GAOR (937th plen. mtg.) at 1158, U.N. Doc. A/PV.937 (1960).

263. Id. at 1159. Ambassador Wadsworth elaborated by adding a common sense conclusion that "the administering authority must trust in the people's wisdom and put their destimy in their own hands." Id. at 1160.

264. M. JANIS, supra note 213 , at 53 . As an example, the prohibition against genocide is widely accepted as jus cogens. Judge Tanaka, in his dissenting opinion in the South West Africa Cases (Ethiopa v. S. Afr.; Liberia v. S. Afr.), 1966 I.C.J. 4, 298 (July 18, 1966), also concludes that the protection of human rights is jus cogens.

265. I. BROWNLIE, supra note 214 , at $82-83$.

266. E.g., Barcelona Traction, Light \& Power Co., (Belg. v. Spain) 1970 I.C.J. 4, 304 (Feb. 5, 1970) (Ammoun, J., separate op.). 
whether or not the principle of self-determination is $j u s$ cogens, it is a norm that is nearly universally accepted. Since the Uinted States has recognized this norm, it is therefore bound by a people's exercise of its right of self-determination.

\section{B. The Process for Negotiation and Approval of the Compact of Free Association Violates Palauans' Right of Self-Determination}

Whether the U.S. negotiations and approval process regarding the Compact of Free Association violate the Palauans' right of self-determination hinges on a question of choice. Does the process allow Palauans freely to determine their political status and pursue their pohitical, economic, and cultural development? Precisely because the United States has severely limited Palauans' free choice on inatters crucial to sovereignty, U.S. actions violate Palauans' right of self-determination.

Throughout the history of trusteeship, including the negotiations on the future political status of the trust territories, the Umited States has insisted on retaining extensive military prerogatives im Palau and elsewhere in Micronesia. ${ }^{267}$ Without question, the United Nations granted the United States significant power to fortify Micronesia and engage im strategic operations there. Article 84 of the U.N. Charter allows the administering authority of a strategic trust to inake use of "facilities, and assistance from the trust territory" for the maintenance of interuational peace and security, as well as for local defense. ${ }^{268}$

During the drafting of article 84, the members of the Five Power Group on Trusteeship debated the "question of fortifications."269 The Umited States intervened to support the proposed langnage because "it would give a right to the Administering Authority for the full use of the military resources of the territory. In so doing, it would remove some of the limitations which had been imposed on former mandates."270 At no time did any participant advocate a complete abolition of limitations on

267. B. ALDRIDGE \& C. MYERS, supra note 25, at 23-39; see also Hearings on H.R.J. Res. 479, Compact of Free Association, supra note 21, at 61-63 (statement of Karl D. Jackson) (describing "geopolitical context" of Palau Compact and U.S. defense interests); The Compact of Free Association Between the United States and Palau: Hearings on H.J. Res. 626 Before the House Comm. on Foreign Affairs and Subcomm. on Asian and Pacific Affairs, 99th Cong., 2d Sess. at 95-100 (1986) (statement of Philip E. Barringer, Ass't Sec'y of Defense for Int'l Security Affairs, Dep't of Defense) ("The Compact with Palau is very clearly in the strategic interest of the United States.").

The Supreme Court of Palau in Fritz v. Salii, App. No. 8-88, slip op. at 20 (Palau Sup. Ct., App. Div., Aug. 29, 1988), described the Compact in terms of a "quid pro quo" arrangement, with Palau offering "access to and nse of portions of Palauan territory on land and sea for United States military strategic purposes," in exchange for money. Id. The court observed that the defense provisions also benefit Palau but are "primarily of military strategic importance to American imterests." Id.

268. U.N. ChARTER art. 84, para. 1.

269. 1(2) U.N. GAOR Annex 18, at 269-70, U.N. Doc A/C.4/40 (1947).

270. Id. at 270 . 
the proprietary state's military, but the implication was that the United States would exercise extensive military authority in the region. ${ }^{271}$ Indeed, the practice of states under the mandate system ${ }^{272}$ had, at times, included the exercise of broad military prerogatives. ${ }^{273}$ The legal rationale for U.S. insistence on a defense veto under the Compact over the foreign and (to some degree) imternal affairs of Palau is generally based on these historical circumstances underlying the strategic trnst designation. ${ }^{274}$

International law, however, confers on neither the United Nations nor a proprietary state the power to establish military policies that contravene the freely expressed wishes of a people in core matters of sovereignty; to permit otherwise would eviscerate the right of selfdetermination. At the core of sovereignty is control over land, natural resources, and foreign relations. ${ }^{275}$ Along with a permanent population, this control is essential to statehood. The Palauans have freely and clearly expressed their interest in keeping nuclear technology and attendant waste by-products out of their islands and water. In addition, the Palauans chose to deprive foreign governments of the right to condemn precious land in their territory. Since these expressed interests he at the core of the Palauans' right of self-determination, the United States cannot claim privileges in Palau that are in conflict with these interests.

In the late 1970s, before and during the drafting of the original Compact of Free Association, the United States declared to the Micronesians its intention to retain military authority in Micronesia. In 1979, the United States informed Palau's Constitutional Commission that denying the United States the benefits of the power of eminent domain would "close the door to a pohitical relationship of free association." 276 In the first round of political status negotiations with the

271. The Egyptian representative proposed an amendment to article 84 to place the administering authority's powers with respect to military "facilities and assistance" under the control of the Security Council. See id. at 272. In response, the U.S. representative asserted that while obligations in regard to the maintenance of international peace and security were already under Security Council control, the Security Council should not be involved in the administering authority's second role-local defense and the law-and-order function within the Trust Territory. See id. The proposed Egyptian amendment was defeated in Counmittee by a vote of 26 to 2 . Id. at 273.

272. For a discussion of the mandate systein, see supra note 163 .

273. For example, in the years following World War I, Japan had a broad military mandate in Micronesia. See generally T. YanAiHARA, Pacific IsLANDS UNDER JAPANESE MANDATE 22-23, 27 (1940).

274. See Hills, Compact of Free Association for Micronesia: Constitutional and International Law Issues, 18 INT'L LAW. 583, 606 (1984); supra text accompanying notes 162-64.

275. Resolution On Permanent Sovereignty Over Natural Resources, G.A. Res. 1803, 17 U.N. GAOR Supp. (No. 17) at 15, U.N. Doc. A/5217 (1963), reprinted in 2 I.L.M. 223 (1963).

276. See Report to the Palau Legislature, Palau Constitutional Drafting Commission, (1979), quoted in Gibbons v. Salii, App. No. 8-86, slip op. at 22, 35-36 (Palau Sup. Ct., App. Div., Sept. 17, 1987). 
Reagan administration, the Micronesians were again reminded of the extent of U.S. strategic interests in their region. U.S. officials stated that the long-term security of the United States required U.S. military bases in Micronesia, the right of denial to unfriendly nations, and "assured rights of access, transit and overflight throughout the Micronesian area."277 The U.S. view of its strategic interests in Palau persisted throughout the course of Coinpact negotiations and the ensuing plebiscites. $^{278}$

U.S. intransigence on matters it considers strategic priorities is tantamount to making the Micronesians' self-determination conditional on their forfeiture of control over national security and a significant amount of internal authority. Because self-determination is not a conditional right, attaching material conditions to the exercise of such a right violates international norms.

In defending itself against allegations that its strategic imperative denies Palauans choice in matters central to sovereignty, the Uinited States has asserted that the trust territories were offered complete independence and therefore had not faced an illegally restricted choice. ${ }^{279}$ But the records of negotiations on the future of Palau and the other trust territories contain scant evidence of U.S. offers to grant independence to Micronesia. And given the progressive dependence of Palau's econoniy on U.S. aid, Palau was in effect foreclosed from choosing the independence option.

In a 1980 article, Professor Clark examined the first draft of the Compact and explored whether that agreement conformed with decolonization norms developed by the United Nations. ${ }^{280}$ Clark used various criteria for evaluating the role of the administering authority of the strategic trnst, including criteria derived froin General Assembly Resolutions 1514 and $1541 .{ }^{281}$ Clark concluded that, although the terms of the Marianas Commonwealth fell short, "[t]he Free Association agreements conteniplated for the renainder of the Trnst Territory probably

277. See Office for Micronesian Status Negotiations, Dep't of State, Summary Record of the Sixth Round of Renewed Political Status Negotiations Between the United States and the Republic of Palau, the Federated States of Micronesia, the Republic of THE MARShall Islands, OCtoBer 3-9, 1981, A2-1 (1983) (statement of Noel C. Koch, Principal Deputy Ass't Sec'y of Defense).

278. See generally supra text accompanying notes 20-25, 118-20.

279. See, e.g., Report of the Trusteeship Council to the Security Council on the Trust Territory of the Pacific Islands, 44 U.N. SCOR Special Supp. (No. 1) at 27, U.N. Doc. S/20843 (1989) ("[T] he Administering Authority had consistently recognized that the Compact of Free Association was not the only political option open to Palau. Independence and commonwealth status had both been included on the ballot at various times.").

280. See Clark, supra note 39, at 66-83.

281. See id. 
conform to the requirements of the relevant United Nations norms."282 Clark based his conclusion on the earlier draft's grant to the Micronesians of freedom to nodify their status unilaterally. ${ }^{283}$

The ensuing negotiations that yielded the existing version of Palau's Compact niade the agreenients "niuch niore onerous for the Micronesians," in Professor Clark's view. ${ }^{284}$ According to Clark, the propriety of the Conpact changed as a result of the provisions that inade U.S. "denial rights" permanent unless terminated by nuutual agreement. ${ }^{285}$ Professor Clark decided that the Conipact was now "contrary to the decolonization norms of the United Nations and just plain unconscionable."286

Attorney David Isenberg, a former legal intern at the Defense Department, differs with Clark. ${ }^{287}$ Although Isenberg acknowledged the potential problem with mutual security agreements that cannot be unilaterally terminated, ${ }^{288}$ he pointed to a number of factors that in his view assure the legal validity of the Conıpact: (1) the territorial government has the "acknowledged capacity to exercise self-determination on future status questions"; 289 (2) the agreenients were approved under constitutional processes; (3) the U.N. plebiscites followed large educational prograins; and (4) the inhabitants understood the effect of the agreenients. ${ }^{290}$ He also cited precedents exemplifying what he called "political alliances which restrict the parties' capacity to enter into other alliances, or to individually take policy positions in conflict with their common interests."291

282. Id. at 84. Clark concludes that the Marianas Covenant does not satisfy any of the tests that apply to resolution of the political status of a trust territory. According to Clark, the Covenant fails to meet standards for self-determination, particularly those of Resolution 1541 and other G.A. resolutions, which require that the peoples concerned must be free to modify their status. See id. at 75-78. For instance, the Covenant fails as an example of "integration with an independent State" because " $[t]$ le inhabitants of the Marianas are not represented in the United States legislature; they may not vote for President; they may be affected by federal legislation which could not be nade applicable to the states." Id. at 76.

283. See id. at 72-73.

284. Clark, Free Association-A Critical View, in Proceedings: Conference oN THE Future Political Status of THE UNITEd States VIRGIN ISLANDS 1, 8-9 \& n.13 (P. Leary ed. 1989).

285. Id. at $11-13$.

286. Id. at 5 .

287. See Coinunent, Reconciling Independence and Security: The Long Term Status of the Trust Territory of the Pacific Islands, 4 UCLA PAC. BASIN L.J. 210 (1985) (autlored by David Isenberg).

288. See id. at 228 ("Significantly, the Umited States indicates that it expects the relationship to continue so long as it desires. The Micronesian states' ultimate status nay well pivot on this fact's legal impact.").

289. Id. at 224.

290. Id.

291. Id. at 232-33. In response, Clark primarily distinguished the precedents cited by Isenberg, pointing out that Isenberg's precedents are all either unilaterally terminable or predate the emergence of modern U.N. decolonization norms. See Clark, supra note 284, at 13-16. 
The issues raised in the Clark-Isenberg exchange potentially call into question the legality of each of the four arrangeinents inade by the United States with former trust territory entities. In the case of the Marshall Islands Compact, for example, it can be argued that as "unconscionable" as the terms inay appear to outsiders, ${ }^{292}$ the arrangeinent represents the freely expressed choice of the people concerned. ${ }^{293}$ International law recognizes the capacity of states in statu nascendi $i^{294}$ to make legally binding arrangements with existing states. According to Brownlie, "once statehood is firmly established, it is justifiable, both legally and practically, to assume the retroactive validation of the legal order during a period prior to general recognition as a state."295 In other words, the Marshallese, as people of an einerging state, were free to grant to other states any rights they wished to grant.

In the case of Palau, the freely expressed choice of the people resulted in a constitution that clashed with U.S. strategic interests. Unlike the Marshallese, the Palauans adopted a constitution that included provisions on niatters central to the sovereiguty of Palau, and the United States found the provisions objectionable. ${ }^{296}$ The United States subsequently ignored the freely expressed wishes of the Palauan people by insisting upon the inamtainance of the nuclear transit and eininent doinam rights denied it under the constitution.

The portions of the Palau Constitution that the United States find objectionable enibrace the Palauans' decisions on such vital issues as: (1) the use of scarce land; (2) environmental health and safety and the choice not to accept both the risks and benefits of nuclear technology; (3) national security and military defense needs; (4) foreign relations and the potential effect that situating nuclear weapons bases in Palau would have on relations with potential allies and trading partners; and (5) doniestic security and the significant forfeiture of police power that nuclear weapons would inevitably involve.

292. Professor Clark concludes that the right of strategic denial granted to the United States in perpetuity under the latest agreements with all three Compact states causes each of the agreements to fail under U.N. standards. Cf. 53 U.N. TCOR (1604th plen. mtg.) at 39-42, U.N. Doc. T/ PV.1604 (1986).

293. Professor Prince, in his 1989 article, examines whether free association represents the freely expressed choice of the eleetorate in the trust territories. See Prince, supra note 13, at 55-59. Though Prince gives credence to Clark's concerns, he ultimately sides with those who find free association legal under existing law nonns. See id. at 56. He indicates, however, that the Security Council should encourage "adjustments" to the terms of free association to require that the right of strategic denial be periodically renegotiable. See id. at 59.

294. In statu nascendi refers to a government evolving into statehood under the Trusteeship Agreement. See J. Crawford, CREation of States in INTERnational Law 391-96 (1979); $c f$. infra note 299 (describing Palau's status as in statu nascendi, and not as a U.S. territory or as property under U.S. sovereignty).

295. I. BROWNLIE, supra note 214 , at 82 .

296. See supra text accompanying notes 58-82. 
Although Palauans could theoretically still freely choose to reverse their earlier choice and grant the constitutionally withdrawn military riglits to tlie United States on a quid pro quo basis, free choice cannot be adequately demonstrated where the United States has placed impossible conditions on Palau: The United States refused to terminate the trusteeship except on terms contrary to the Palau Constitution. The difficulty of demonstrating that a deeision to accede to U.S. deniands would genuniely be free clioice is conipounded in Palau because tlie Republic is so thoroughly dependent on U.S. aid. Thus, even if approved, tlie Conipact would not satisfy the free choice requirenient inherent in the Palauans' right of self-determination under international law.

\section{The Compact of Free Association, Even if Approved, Would Be Void or Voidable Under the International Law of Treaties}

\section{The Vienna Convention Governs the Validity of the Compact}

The Trnsteeship Agreement has tlie nature and force of a treaty; ${ }^{297}$ treaties can and generally do create obligations that are binding on the parties under international law. ${ }^{298}$ Because the legal relationship between Palau and the United States is governed by international law, it differs from a traditional bilateral relationship between a protecting power and a nonsovereign protectorate. ${ }^{299}$ Performance under the Trusteeship Agreenient and any Conipact of Free Association or otler agree-

297. See, eg., H. KELSEN, supra note 230, at 332 ("These trusteeship agreements are treaties concluded by the United Nations on the one hand, and the states competent to dispose of these territories on the other hand."). An analogy to the former Umited Nations Mandate system is useful. The International Court of Jnstice in the South West Africa Cases ruled on the question of the legal force of the Mandate; a majority of the court held that "the Mandate, in fact and in law, is an international agreement having the character of a treaty or convention." South West Africa Cases (Ethiopia v. S. Afr.; Liberia v. S. Afr.), 1962 I.C.J. 319, 330 (Dec. 21, 1962).

298. RESTATEMENT (THIRD) OF THE Foreign RELATIONS LAW OF the UNITED States $\S 102$ comment f (1987).

299. The territorial clause of the U.S. Constitution gives Congress certain authority over "the Territory or other Property belonging to the United States." U.S. CoNST. art. IV, § 3, cl. 2. At no time could this provision govern the relationship between Palau and the United States: Palau has never been a territory or property of the Umited States and has never been under U.S. sovereignty. United States. v. Covington, 783 F.2d 1052, 1055 (9th Cir. 1985); People of Saipan v. United States Dep't of Interior, 502 F.2d 90, 95 (9th Cir. 1974).

Since the 1960 s, Palau and the rest of the trust territory has been in statu nascendi. Juda v. United States, 13 Cl. Ct. 667, 677 (1987); see J. CRAWFORD, supra note 294, at 391-96. Therefore, negotiations with the Umited Nations and with the peoples of the emerging states are analogous to treaty negotiations under international law.

Under U.S. law, the President exercises the primary authority to negotiate the changes in political status of the trust territories under the treaty-naking power. See U.S. CoNsT. art. II, § 2, cl. 2; United States v. Pink, 315 U.S. 203, 229-30 (1942); Umited States v. Curtiss-Wright Export Corp., 299 U.S. 304, 319-20 (1936). Because the trust territories are not territories but more like foreign entities, U.S. legislative authority derives solely from the "necessary and proper clause." See U.S. CoNST. art. I, $\S 18$, cl. 8; Missouri v. Holland, 252 U.S. 416, 432 (1920). For a general discussion of the territorial clause issne, see Hills, supra note 274 , at 587-88, 592-97. 
ment for termination of trusteeship must conform with international law norms, mcluding the law of treaties.

The Vienna Convention on the Law of Treaties, ${ }^{300}$ also called the Treaty on Treaties, came into force in $1980 .{ }^{301}$ To date, the United States still has not ratified the Convention; however, under official U.S. pohicy, the convention is regarded as "the authoritative guide to current treaty law and practice." 302 Under the Vienna Convention, a treaty is void if it: (1) conflicts with a peremptory norm of general international law; $;^{303}$ or (2) is procured by coercion of a state. ${ }^{304}$ In addition, a treaty is voidable if the treaty is procured through corruption of its representative. ${ }^{305}$

These sections of the Convention on invalidity of treaties are vital to the law of treaties and have significant legal weight. ${ }^{306}$ However, because a number of the participants at the Vienna Convention, including many of the Western powers, expressed reservations about these provisions, ${ }^{307}$ the extent to which they apply to the Compact of Free Association requires analysis.

\section{The Validity of the Compact Under the Vienna Convention}

A strict application of the Vienna Convention's rules governing the voidability of treaties to Palau's Coinpact with the United States would threaten the validity of that agreement. There are three bases for finding the Coinpact, even if now approved constitutionally, void or voidable under the law of treaties: (1) the Compact violates a rule of jus cogens, namely Palau's right of self-determination; (2) the Compact was procured through coercion; and (3) the Coinpact was procured through the corruption of a state representative.

\section{a. Violation of the Right of Self-Determination}

We have seen that there is growing authority for defining the right of self-determination as jus cogens, along with other basic human

300. Vienna Convention on the Law of Treaties, adopted May 23, 1969, 1155 U.N.T.S. 331 [hereinafter Vienna Convention].

301. See Summary Records of the 1586th Meeting, [1980] 1 Y.B. INT'L L. CoMm'N 5, U.N. Doc. A/CN.4/SER.A/1980.

302. Vienna Convention on the Law of Treaties: Message from the President of the United States, 7 Weekly Comp. Pres. Doc. 1556 (Nov. 21, 1971).

303. Vienna Convention, supra note 300 , art. 53.

304. Id. art. 52.

305. Id. art. 50.

306. Frankowska, The Vienna Convention on the Law of Treaties Before United States Courts,

28 VA. J. INT'L L. 281, 368 (1988).

307. See Nahlik, The Grounds of Invalidity and Termination of Treaties, 65 AM. J. INT'L L. 736, 737 (1971); see also Frankowska, supra note 306, at 293-95. 
rights. $^{308}$ This view, however, is not universally accepted. ${ }^{309}$ While drafting article 53 (then article 37), the International Law Commission, a U.N. advisory group of jurists, considered histing specific jus cogens norms whose violation would void a treaty. ${ }^{310}$ In the draft commentaries, self-determination was among the half dozen suggested rules of $j u s$ cogens. ${ }^{311}$ The Commission eventually decided against including any such examples, but its dehiberations nearly three decades ago demonstrate early suggestion of the peremptory nature of self-determination.

To qualify as jus cogens, according to the terms of article 53, a norm must be "accepted and recognized by the international community of states as a whole as a norm from which no derogation is permitted."312 The U.S. delegate to the Conference on the Law of Treaties interpreted the language to inean that "a rule of international law was ouly jus cogens if it was universal in character and endorsed by the international community as a whole." ${ }^{313}$ Recent world events support a conclusion that self-determination, for niost people heretofore populating territories, has developed into a peremptory norm. ${ }^{314}$ Admittedly, in international jurisprudence, the concept of jus cogens in general, and specifically of self-determination as jus cogens, is still nascent. ${ }^{315}$ But a sufficient body of opinion exists for an international tribunal to rule that the right of selfdetermination is jus cogens. Therefore, the Conipact could be voided under article 53, as a violation of Palau's right of self-determination.

308. See supra text accompanying notes $265-67$.

309. See supra notes 229-30 and accompanying text.

310. Report of the International Law Commission to the General Assembly, 18 U.N. GAOR Supp. (No. 9) at 11-12, U.N. Doc. A/5509 (1963), reprinted in [1963] 2 Y.B. INT'L L. COMM'N 187, 198-99, U.N. Doc. A/CN.4/SER.A/1963/Add.1.

311. In addition to self-determination and other "norms protecting human rights," the Commission considered the following: norms against international crimes, rules for the suppression of slave trade, piracy, and genocide, and the U.N. Charter prohibitions against the nse of force. Id., reprinted in [1964] 2 Y.B. INT'L L. COMM'N at 199.

312. Vienna Convention, supra note 300 , art. 53.

313. United Nations Conference on the Law of Treaties, 1st Sess. (52d intg.) at 295, U.N. Doc. A/Conf.39/11 (1969).

314. The most recent examples include the independence of Namibia from South Africa and the disintegration of Soviet domination of Eastern Europe.

315. In a 1974 survey of the World Court's opinions, Professor Sztucki identified six mentions of jus cogens or peremptory norms, all in separate or dissenting opinions. See J. SzTUCK1, Jus Cogens and the Vienna Convention on the LaW of Treaties: A Critical Appraisal 1216 (1974). More recently, in the Nicaragua case, supra note 257, at 90, the International Court of Justice cited references by states and jurists to jus cogens to support its conclusion that the prohibition against the use of force is a rule of customary international law. Judge Ammoun asserted in his separate opinion in Barcelona Traction, Light, \& Power Co. (Belg. v. Spain), 1970 1.C.J. 3 (Feb. 5, 1970), that the right of self-determination is jus cogens, id. at 304, and elsewhere extolled "the imperative right of peoples to self-determination," see Legal Consequences for States of the Continued Presence of South Africa in Nanibia (South West Africa) Notwithstanding Security Council Resolution 276 (1970), 1971 1.C.J. 16, 75 (June 21, 1971) (separate opimion of Ammoun, J.). 


\section{b. The Use of Coercion}

The second basis for finding the Compact void is coercion of the state by threat or use of force. Although little case law exists on the Vienna Convention's invalidation articles, it is widely accepted that article 52 outlaws the use of force to obtain consent to a treaty's obligations. $^{316}$ Thus, arguments could be predicated on the force implicit in the U.S. military presence in Palau and the Pacific region generally. However, since U.S. atomic testing ended in the Pacific, the U.S. presence in the area generally has not been regarded as coercive.

A more significant argument is predicated on interpreting the "threat or use of force" to encompass economic coercion. As previously discussed, the Umited States bears much of the responsibility for Palau's extreme economic dependence. This Comment earlier concluded that this dependency, coupled with U.S. intransigence in negotiating the security provisions of the Compact, violates the Palauans' right of selfdetermination. ${ }^{317}$ The question arises whether U.S. use of its economic leverage in Palau to gain nuclear transit and eminent domain rights constitutes a "use of force" under article 52.

The participants in the Vienna Conference debated but failed to agrec that "economic coercion" falls within the anbit of the prohibition against sucll a use of force. The United States figured prominently ainong the delegations opposed to allowing a claim of economic coercion to mvalidate a treaty. ${ }^{318}$ It becaine apparent, lowever, that the majority of the participants favored broadening the definition of force to include economic coercion; ${ }^{319}$ the treaty itself leaves "force" undefined. Nevertheless, the history of the draftimg of the Vienna Convention strongly implied that interpretation of "the threat or use of force" in article 52 would eventually ripen to encompass the threat or use of economic coercion.

The principle embodied in article 52 has undergone a steady development and expansion. Traditional customary law did not even include the concept that force would vitiate consent. ${ }^{320}$ This principle against invalidation of treaties began to erode in 1949, when the International Law Commission undertook to draft a code of treaty law. In his first Report on the Law of Treaties, Special Rapporteur Sir Hersch Lauterpacht concluded that international law had changed to the point

316. Frankowska, supra note 306 , at 369.

317. See supra text accompanying notes 170-78, 182-88.

318. See United Nations Conference on the Law of Treaties, 1st Sess. (52d mtg.) at 292, U.N. Doc. A/Conf.39/11 (1969).

319. See id.

320. At one time, even a treaty signed under threat or use of force was valid and enforceable. See Second Report on the Law of Treaties, [1963] 2 Y.B. INT'L L. COMM'N 36, 51, U.N. Doc. A/ CN.4/SER.A/1963/ADD.1. 
that a treaty secured by coercive means would be invalid if the International Court of Justice so declared. ${ }^{321}$

Sir Gerald Fitzmaurice, Lauterpacht's successor as Special Rapporteur of the International Law Commission, no longer found a decision by the International Court of Justice necessary in order for a treaty to be invalidated on the grounds of coercion. ${ }^{322}$ But Fitzmaurice, concerned about a potentially destabilizing expansion of the principle, insisted that "[t]he case must evidently be confined to the use or threat of physical force, since there are all too numerous ways in which a State might allege that it had been induced to enter imto a treaty by pressure of some kind (for example, economic)."

Fitzmaurice's concern must be viewed in hight of an already coalescing movement to include economic coercion in the U.N. Charter's article 2(4) prohibition agamst the threat or use of force. This concept first gained widespread recognition through incorporation into articles 15 and 16 of the Charter of the Organization of American States. ${ }^{324}$ The principles are now set forth in articles 18 and 19 following a Protocol of Amendment. ${ }^{325}$ This document entered into force for the Umited States on February 27, 1970.

In a 1963 report, the Interuational Law Commission's fourth Special Rapporteur, Sir Humphrey Waldock, spelled out the pitfalls of allowing economic pressure to be construed as coercion for the purposes of invalidating a treaty. Waldock asserted:

[I]f "coercion" were to be regarded as extending to other forms of pressure upon a State, to political or economic pressure, the door to the evasion of treaty obligations might be opened very wide; for these forms of "coercion" are much less capable of definition and mucl more liable to subjective appreciations. Moreover, the operation of political and economic pressures is part of the normal working of the relations between States, and international law does not yet seem to contain the criteria necessary for formulating distinctions between the legitimate and illegitimate uses of such forms of pressure as a means of securing consent to treaties. ${ }^{326}$

Waldock then concluded that "it would be unsafe in the present state of international law to extend the notion of 'coercion' beyond the illegal use

321. See Report on the Law of Treaties, [1953] 2 Y.B. INT'L L. COMM'N 90, 147, U.N. Doc. A/ CN.4/SER.A.1953.

322. See Law of Treaties, [1958] 2 Y.B. INT'L L. COMM'N 20, 38, U.N. Doc. A/CN.4/SER.A/ 1958/Add.1.

323. Id. (emphasis in original).

324. 2 U.S.T. 2394, T.I.A.S. No. 2361, 119 U.N.T.S. 3.

325. 21 U.S.T. 607 , T.I.A.S. No. 6847.

326. Second Report on the Law of Treaties, [1963] 2 Y.B. INT'L COMM'N 36, 52, U.N. Doc. A/ CN.4/SER.A/1963/ADD.1. 
or threat of force."327 His carefully chosen words reveal that he contemplated the development of imternational law eventually to include both economic and physical coercion as grounds to invalidate a treaty. ${ }^{328}$

The fifteenth session of the International Law Commission, also held in 1963, included extensive discussion during the drafting of thenarticle 12 (later article 52) of the kinds of coercion that could vitiate consent to be bound to treaty obligations. ${ }^{329}$ The delegates agreed in the final language that "the threat or use of force" could include economic and pohitical coercion. ${ }^{330}$

Even as the draft code of the Law of Treaties took shape, a prohibition against the use of economic pressures in relations between states increasingly gained the character of a general principle of law within the meaning of article 38 of the Statute of the International Court of Justice. $^{331}$ In 1965, The U.N. General Assennbly approved Resolution 2131 (with one abstention and no dissenting votes), which condeinns "armed intervention and all other forms of interference or atteinpted threats against the personality of the State or against its political, economic and cultural elements."332 The Resolution further declares that "[n]o State may use or encourage the use of economic, pohtical or any other type of measures to coerce another State in order to obtain froin it the subordination of the exercise of its sovereigu rights or to secure froin it advantages of any kind."333 The Resolution attests to the developing practice ainong states to refrain from and to condemn economic as well as armed intervention.

In 1968, at the 48th meeting of the International Law Counmission, mineteen states introduced a jomt amendment to the Law of Treaties ${ }^{334}$ on the grounds that "[e]conomic and pohtical pressure was contrary to the right of political and economic self-determination."335 Opponents of the "nineteen-amendment" raised a number of objections: (1) " "political and economic pressure' had not yet been adequately defined and estabhished $\mathrm{m}$ law to be included $\mathrm{m}$ the convention as a ground for imvalidat-

327. Id. (emphasis added).

328. See Brosche, The Arab Oil Embargo and the United States Pressure Against Chile: Economic and Political Coercion and the Charter of the United Nations, in ECONOMIC CoERcioN AND THE NEW INTERNATIONAL ECONOMIC ORDER 285, 310 (R. Lillich ed. 1976) (hereinafter ECONOMIC COERCION] (characterizing Waldock's approach as an "open-ended formulation").

329. See Summary Records of the 15th Session, [1963] 1 Y.B. INT'L L. COMM'N 53, 212-13, U.N. Doc. A/CN.4/SER.A/1963.

330. See id. at 212-13, 312-13.

331. ICJ Statute, supra note 214 , art. 38.

332. G.A. Res. 2131, 20 U.N. GAOR. Supp. (No. 14) at 11-12, U.N. Doc. A/6014 (1965) (emphasis added).

333. Id.

334. United Nations Conference on the Law of Treaties, 1st Sess. (48tl $\mathrm{mtg}$.) at 269, U.N. Doc. A/Conf.39/11 (1969).

335. Id. at 269-70. 
ing a treaty"; ${ }^{336}$ (2) extending the definition of the "threat or use of force" to include "all forms of pressure exerted by one State on another, and not just the threat or use of armed force" would make the scope "so wide as to tnake it a serious danger to the stability of treaty relations"; 337 and (3) allowing a treaty to be voided on the grounds of economic coercion potentially creates a de facto contractual incapacity for any lesser economic entity. ${ }^{338}$

The U.S. delegate, speaking against the nineteen-state amendınent, offered a variation of the major arguments of the amendinent's opponents. According to the United States, "the concept of 'economic or political pressure' ... was so lacking in juridically acceptable content as to cast grave doubts on any article containing it."339 On a nore practical level, the United States predicted that the amendment would hurt the poorer countries because "[i]nvestors would regard the amendnient as nicreasing their risks and would raise the cost of their nivestnients."

A strong majority of the delegations at the Viemia Conferencc supported the nineteen-state amendment, but the dozen states opposing it included most of the world's economic powers. It is noteworthy that the amendment's opponents universally condemned the use of economic pressure to force acceptance of a repugnant agreement, and the United Kingdom even acknowledged that cases might exist "where flagrant economic or pohtical pressure amounting to coercion could justify condemnation of a treaty." 341

In the end, the niajority did not press for a vote. The Afgham delegate explained that the sponsors of the amendment "did not wish to take advantage of their majority to impose their point of view on the minority, but they did ask it to try to understand their position and not to demand that they sacrifice their interests because the minority was powerful." ${ }^{342}$

The issue was resolved through the adoption of a Draft Declaration on the Prohibition of the Threat or Use of Economic or Pohtical Coercion in Concluding a Treaty, which condemns "the threat or use of pressure in any form, military, political, or economic, by any State in order to coerce another State to perform any act relating to the conclusion of a treaty in violation of principles of sovereign equality of States and freedoni of consent." ${ }^{343}$ The declaration forms part of the Finial Act of the

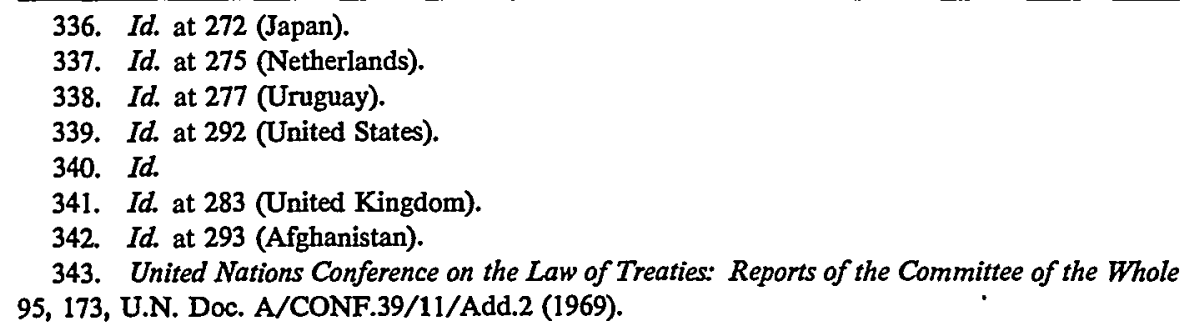


Conference on the Law of Treaties and is itself evidence of the development of customary international law on the question of economic coercion and the validity of treaties.

More recent evidence of the force and vitality of a principle barring the use of economic coercion is found in the influential Declaration on Principles of International Law Regardimg Friendly Nations, adopted by acclamation in $1970 .{ }^{344}$ Declaration 2625 provides that "[n]o State may use or encourage the use of economic ... measures to coerce another State im order to obtain from it the subordmation of the exercise of its sovereign rights and to secure from it advantages of any kind."345

This language and the language of other documents which are indicia of norm creation ${ }^{346}$ can be imterpreted as creating a distimction between economic pressure apphed to gam pohtical advantages or constram the exercise of sovereign rights, and economic pressure apphed for merely economic reasons. ${ }^{347}$ Under such a formulation, the standard of proof is great, ${ }^{348}$ but one can nonetheless argue that actions like the Arab oil embargo of 1973 violated the U.N. Charter's article 2, paragraph 4 bar agaimst the use of force. ${ }^{349}$

With current trends favoring those who would interpret the prohibition agaimst force to include economic coercion, ${ }^{350}$ a test case arising under the Law of Treaties might bring significant results. A challenge to Palau's obligations under the Compact of Free Association between Palau and the Umited States could be the case to signal the new view of article 52.

In Palau, the evidence of economic coercion provides a textbook answer for the minority opposed to the recognition of economic coercion as a grounds for voiding a treaty. The greater power, after assuming an obhigation to foster the protectorate's self-sufficiency, imstead allows a progressive dependence to develop. During negotiations over future pohitical status, the greater power declares its imterests nounegotiable even in the face of the freely expressed contrary wishes of the protector-

344. G.A. Res. 2625, 25 U.N. GAOR Supp. (No. 28) at 121, U.N. Doc. A/8028 (1970).

345. Id. at 123.

346. See, e.g., Charter of Economic Rights and Duties of States, G.A. Res. 3281, 29 U.N. GAOR Supp. (No. 31) at 55, U.N. Doc. A/9631 (1974); Permanent Sovereignty Over Natural Resources, G.A. Res. 3171, 28 U.N. GAOR Supp. (No. 30) at 53, U.N. Doc. A/9030 (1973).

347. Brosche, supra note 328, at 307; see also Bowett, International Law and Economic Coercion, in ECONOMIC COERCION AND THE NEW INTERNATIONAL ECONOMIC ORDER 89, 93 (R. Lillich ed. 1976).

348. See Editorial Comment, Political and Economic Coercion in Contemporary International Law, 79 AM. J. INT'L L. 405, 411 (1985) (authored by Tom J. Farer).

349. See, eg., J. StONe, CONFlict Through CONSEnsus 64 (1977); Paust \& Blaustein, The Arab Oil Weapon-A Threat to International Peace, 68 AM. J. INT'L L. 410, 415 (1974) (explaining how and when article 2, paragraph 4 of the U.N. Charter is violated).

350. See Brosche, supra note 328 , at 312 . 
ate's people. The greater power then withholds from the dependent territory both sovereignty and a needed economic infusion pending approval of its nonnegotiable terms.

The facts surrounding the Compact negotiations in Palau offer a clear example of the kind of economic coercion condemned by the Vienna Conference. ${ }^{351}$ Here, economic coercion is easily distinguished from typical negotiations between states, even where one state has overwhelmingly superior bargaining power. Seldom will the disparity of size and wealth between states be so great, and seldom will the greater power have such a deeply entrenched interest in using its economic advantage to maintain its rights and privileges within the borders of the lesser state. Moreover, the peculiar economic dependence of Palau on the United States, which arose and worsened even as the Umited States was under a legal obligation to pronote Palauan self-sufficiency, makes this example of economic coercion unusually flagrant.

\section{c. Corruption of a State Representative}

A third threat to the validity of the Compact under the Law of Treaties arises over questions of corruption. According to article 50 of the Vienna Convention, a treaty is also voidable if "consent to be bound by a treaty has been procured through the corruption of its representative directly or indirectly by another negotiating State."352 In Palau, the strongest evidence of corruption that might invalidate Palau's consent to be bound is connected with former President Lazarus Salii, now deceased. ${ }^{353}$ But allegations that U.S. involvement in Palau's pohtical processes exceeded the bounds of fair play surfaced even before Palau

351. Professor Prince recently addressed the implications of possible economic coercion in Palau. See Prince, supra note 13, at 66-67. The issue, in Prince's words, is "whether the United States stepped across the line from fair but liard bargaining to the use of economic coercion." Id. at 66. Prince suggests putting the issue ou the agenda for Security Council consideration and concludes that "the question can only be resolved through a carefully conducted factual investigation." Id. at 67.

352. Vienna Convention, supra note 300, art. 50. Aecording to Ian Siuclair, no state has ever invoked corruption as grounds for invalidating treaty obligations. See I. SINCLAIR, VIENNA CONVENTION OF THE LAW OF TREATIES 174-75 (1984). In the absence of jurisprudence on the provision, the International Law Conımission's commentary offers scant material for workable legal standards. However, according to the Commission, "only acts calculated to exercise a substantial influence on the disposition of the representative to conclude the treaty may be invoked." United Nations Conference on the Law of Treaties: Draft Articles on the Law of Treaties with Commentaries 7, 65, U.N. Doc. A/CONF.39/11/Add.2 (1969). Such acts would be distinguished froin "a sinall courtesy or favour." Id.

353. Salii, about whoin questions later arose, see infra note 356 , was intimately involved with negotiations for the Compact beginning as carly as 1967, when lie chaired the Micronesian Political Status Commission. D. MCHENRY, supra note 42, at 89 . As previously noted, Salii had come to the attention of American officials as a potential political ally in the effort to secure agreenents favorable to U.S. interests in Micronesia. See U.S. Government Survey Mission to the Trust Territory of the Pacific Islands: Report to the President (A. Solonion, Oct. 9, 1963) (confidential version). Salii's 
became a Republic and elected its first president. ${ }^{354}$ For example, when Haruo Remeliik reversed his opposition to the Compact after being elected Palau's first president, some suspected bribery. ${ }^{355}$ Evidence of large-scale corruption, lowever, only came to light during the Salii presidency. ${ }^{356}$

In connection with the 1988 power plant scandal involving the Britislı company International Power Systems Co., Ltd. (IPSECO), ${ }^{357}$ Congress eventually learned that the Britislı contractor had paid \$1 million to Palauan and other officials. ${ }^{358}$ Salii received two separate payments of $\$ 100,000$ each while he was Palau's Compact and trade negotiator witlı "full autlıority to represent, negotiate and commit Palau to [Compact] agreements." 359 He reportedly then convinced the U.S. Compact negotiator, Ambassador Fred M. Zeder II, to pledge to the guarantor banks that Compact funds could be used to pay for the power plant. $^{360}$

The bribes paid to Lazarus Salii were sufficiently tied to passage of the Compact to taint Salii's subsequent role as a negotiator and leading proponent of the passage of the Compact. Salii's advocacy of the Compact eventually also included direct pressure on government workers. ${ }^{361}$ As is true of any elected political leader, Salii undoubtedly had the power to deliver the votes of those Palauans who trusted his representation of their interests during negotiations. ${ }^{362}$ As the facts subsequently revealed, this trust was misplaced. ${ }^{363}$

career is summarized in a 1990 book on the political relationship between Palau and the United States. See B. AldRIDGE \& C. MYERS, supra note 25, at 42-43.

354. One writer, for example, alleged that the Uirited States gave direct cash payments to proAmerican opponents of Palau's antinuclear Constitution, and that CIA operatives did door-to-door canvassing. See Arakawa, Palau's Constitutional Struggle: Micronesia Strives for a Nuclear-Free Future, 12 AMPO: JAPAN-ASIA Q. REV., No. 3, at 15-16 (1980).

355. B. ALDRIDGE \& C. MYERS, supra note 25 , at 81.

356. Official investigations followed reports of corruption made in the popular press. See, e.g., San Jose Mercury News, Nov. 29, 1987, at 1A, col. 4; San Jose Mercury News, Mar. 3, 1988, at 1A, col. 1; McGrory, Arms and the Women, Wash. Post, Jan. 26, 1988, at A2, col. 5; Anderson, Widespread Corruption in Palau, Oakland Tribune, May 19, 1988, at A11, col. 2; Anderson, Trouble in Palau, Wash. Post, May 15, 1988, at B7, col. 1.

357. See supra note 176 and accoinpanying text.

358. See Statement of De Lugo, supra note 15, at 17.

359. GAO Report, supra note 174, at 91 . In addition to the direct payınents to Salii, IPSECO paid \$250,000 to Salii's brother, then-Speaker of Palau's House of Delegates, id. at 93, and \$50,000 to a Palau businessman described as a "close political ally" of Salii, statement of De Lugo, supra note 15 , at 5 .

360. Stateinent of De Lugo, supra note 15 , at 5 .

361. See Guam Tribune, Dec. 9, 1986, at 4, col. 3.

362. See Hearings on H.R.J. Res. 479, Compact of Free Association, supra note 21, at 149 (stateinent of Speaker Santos Olikong) ("Many of our people do not read the amendments. Many of our people do not liave the power of language. So they rely on the people that have that in them, people like us, people hike the executive brancl and the judiciary branch.").

363. Investigators unearthed other examples of corrupt dcalings in Palau, unany, but not all, 
Under the terms of article 50, the corruption alleged must be attributable to the state seeking to enforce the treaty, here the Umited States. According to Ian Sinclair, "it is not enough, under Article 50, merely to establish that the representative has been corrupted; it must be shown that the corruption has been effected directly or indirectly by the other negotiating State." ${ }^{364}$ However, it has been suggested that it is sufficient that the corruption comes from an agent of the state that seeks to enforce the treaty, as long as the act is imputable to the state. ${ }^{365}$

Soine observers of corruption in Palau attribute the corruption directly to the U.S. government. ${ }^{366}$ Corruption is seen as implicit in the promise of large sums of inoney to Palau under the front-loaded payment schedule of the Compact. ${ }^{367}$ There is evidence that U.S. officials used the promise of Compact-tied largesse to gain support froin Palau's leaders. ${ }^{368}$

Allegations of large-scale direct corruption of Palauan officials by U.S. officials, however, have not been confirmed. The public record currently does not hold enough evidence of corruption sufficiently imputable to the Umited States to sustain a claim under article 50 of tle Vienna Convention. Nevertheless, more proof may come to liglit with time, since not all available evidence of corruption lias been sufficiently

related to Salii's activities. For example, $\$ 90,000$ in government funds was used to lease and renovate a house occupied by Salii. See GAO Report, supra note 174, Supp. at 29-32.

364. I. SINCLAIR, supra note 352, at 175 (citing Elias, Problems Concerning the Validity of Treaties, 134 RECUEIL DES COURS 377-78 (1971)).

365. See id. at 175-76 (citing P. REUTER, INTRODUCTION AU DROIT DES TRATTES 171 (1972)).

366. A presidential candidate, Mr. Roman Tmetuchl, "accused Washington of foisting a 'grossly overpriced' power generator on the country in collusion with two former presidents in order to bring pressure on Palau to change the nuclear-free provision in the constitution." Financial Times, Nov. 3, 1988, at 6, col. 3. In 1986, ACLU lawyers representing three inen appealing convictions for the assassination of President Remeliik told the press that there was sufficient basis to raise questions concerning U.S. motives "to weaken Palau" with the power plant contract "in order to make it inore likely to accept the defense compact [sic]." Wash. Post, Nov. 30, 1986, at A18, col. 1.

367. Title II provides for Uirited States economic assistance to Palau. Compact of Free Ass'n, supra note 1, tit. II, art. I. Included under grant assistance is a series of annual outlays to pay for government operations during the first 15 years following the termination of the trusteeship. See id. $\S 211$. In addition, large one-time grants for capital improvements will be provided in the first year or two of the Compact. See id. $\$ \S 211-212$. The total grant assistance for the first year comes to approximately $\$ 140$ million. See id. $\$ \S 211-213$. The largest single item budgeted for the first year is a trust fund of $\$ 66$ million to provide interest income of $\$ 15$ million annually after 15 years of the Compact. See id. \$211. The second-year grants total approximately $\$ 30$ million. See id. tit. II, art. I; see also Hearings on H.R.J. Res. 626, Compact of Free Association, supra note 120, at 67 (testimony of Ambassador Zeder).

368. Ambassador Zeder described the funds available under the Compact in a 1986 letter to Salii extolling the financial rewards of Compact approval. See Letter froin Fred M. Zeder II to President Lazarus Salii (Nov. 28, 1986). Zeder's conclusion that the Compact would be worth approximately three times more to Palau than funding under trusteeship (\$420 million versus $\$ 150$ million) proved to be a gross mistake or misrepresentation. The GAO made its own calculations and concluded that "compact funding is now less generous than we project Palau would receive if trusteeship funding were continued for the next 15 years." GAO Report, supra note 174, at 53. 
investigated. ${ }^{369}$ The Uinted Nations has not yet engaged in factfinding commensurate with the efforts of the United States government (notably the GAO) to date. Under these circunistances, the United States should be aware that corruption in Palau could still pose a threat to the validity of the Conipact.

On balance, the record of U.S.-Palau Coinpact negotiations and the tortured and still unfinished approval process render the Conipact an agreement of questionable validity. Palau can raise several challenges under the Law of Treaties and point to the cumulative failings of the United States as administering authority. In its deahings with Palau, the United States has crossed what Sir Hersch Lauterpacht called "the line between impropriety and illegality, between discretion and arbitrariness, between the exercise of the legal right to disregard the recominendation and the abuse of that right."370 It has thereby exposed itself to legal sanction. A state, according to Lauterpacht, "niay not be acting illegally by declining to act upon a recommendation or series of recommendations on the same subject. But in doing so it acts at its peril when a point is reached when the cumulative effect of persistent disregard of the articulated opimion of the [United Nations] is such as to foster the conviction that the State in question has becone guilty of disloyalty to the Principles and Purposes of the Charter." ${ }^{371}$ By ignoring Palauans' right to selfdetermination, by using its economic leverage coercively, and by allowing - or worse, participating in -the corruption of Palauan officials to secure passage of the Compact, the United States has denionstrated significant disloyalty to fundamental principles of international law and the U.N. Charter.

\section{CONCLUSION}

By an accident of history and geography, when Palau was liberated fronı Japanese Mandate along with nuch of Micronesia, it soon became part of the world's only strategic trust. This arrangenient eventually placcd U.S. strategic interests at odds with the Palauans' right of selfdetermination.

Under conteniporary international law, a conflict between a people's right of self-determination and a military power's strategic interest can have only one legally correct outcome: Palauans' right of self-determina-

369. A GAO investigator told the press that the GAO investigators had "Inore leads about corruption in Palau than they have time to follow." Anderson, Trouble in Palau, Wash. Post, May 15,1988 , at B7, col. 1 .

370. Voting Procedure on Questions Relating to Reports and Petitions Concerning the Territory of South-West Africa, 1955 I.C.J. 67, 115 (June 7, 1955).

371. Id. 
tion trumps the U.S. determination to project its nuclear force throughout Micronesia.

Throughout the world, the United States negotiates with sovereign states to estabhish military bases or make port calls by nuclear vessels within the territory of the foreign sovereign. These arrangements are made under the law of the host nation. In Palau, the desired military privileges violate the Palauan Constitution, and the United States should respect that source of law as it would the constitution of any other sovereign.

The Trusteeship Agreement with the United Nations did not guarantee nuclear transit rights to the United States, nor did it guarantee the United States access to Micronesian land in perpetuity. But the agreement, read im conjunction with custoinary imternational law, does con1inand respect for the freely expressed wishes of Palauans in inatters central to their sovereiguty-control of their territory and protection of their environment. These wishes cannot be subverted by the threat of economic abandonment if U.S. strategic interests are not satisfied.

To secure legally the military rights it seeks in Palau, the United States must first fulfill its obligations under the Trusteeship Agreement and custoinary international law. It must guarantee Palauans the right of self-determination without conditions, and then gain approval froin the U.N. Security Council for termination of the Trusteeship. The United States could then open negotiations on securing nuclear transit rights and military facilities with the sovereign state of the Republic of Palau. 
